\title{
LIETUVOS KARO AVIACIJOS 1919-1940 M. SKRAIDANČIOJO PERSONALO RENGIMO SISTEMA
}

\author{
Mindaugas Sereičikas \\ Klaipedos universiteto Baltijos regiono istorijos \\ ir archeologijos institutas
}

Anotacija. Šiame straipsnyje analizuojama Lietuvos karo aviacijos 19191940 m. skraidančiojo personalo rengimo sistema. Siekiama nustatyti, kaip buvo rengiami lakūnai ir oro žvalgai, aptarti konceptualius rengimo sistemos pokyčius. Straipsnyje skraidančiojo personalo rengimo sistema analizuojama pagal autoriaus sudaryta analizés modeli, kuri sudaro trys pjūviai: atranka, rengimo pakopos ir programa bei rengimo priemones ir jame dalyvavę kariai.

Pagrindiniai žodžiai: Lietuvos karo aviacija, skraidantysis personalas, rengimas, Karo aviacijos mokykla.

\section{IVADAS}

Viena pagrindinių karinio potencialo sudedamųjų dalių yra karinio personalo pasiruošimas vykdyti skirtas užduotis. Šiame kontekste ypač svarbus individualus ir kolektyvinis kovinis rengimas. Siekiant užtikrinti kario tinkamą pasirengimą atlikti karines užduotis, jis nepertraukiamai treniruojamas ir mokomas. 1919 m. kuriant Lietuvos karo aviaciją ${ }^{1}$, kartu buvo pradèta kurti skraidančiojo personalo - lakūnų ir oro žval-

1 Pastaba. 1919-1940 m. Lietuvos kariuomenès ginkluotųjų oro pajègų pavadinimas buvo keičiamas 4 kartus: $1919 \mathrm{~m}$. kovo 12 d.-1920 m. rugsèjo $21 \mathrm{~d}$. - Aviacijos dalis, 1920 m. rugsejjo 22 d.-1921 m. birželio 27 d. - oro laivynas, $1921 \mathrm{~m}$. birželio 28 d.1933 m. vasario 14 d. - aviacija, 1933 m. vasario 15 d. -1940 m. spalio 28 d. - karo aviacija. Straipsnyje, neatsižvelgiant ị laikotarpị, vartojamas paskutinis pavadinimo variantas, o nurodant šaltinius - šaltinyje esantis pavadinimas. 
$\mathrm{guc}^{2}-$ kovinio rengimo sistema. Nors individualus Lietuvos karo aviacijos skraidančiojo personalo ${ }^{3}$ rengimas nèra visiškai naujas tyrimo objektas istoriografijoje, iki šiol daugiausia dèmesio buvo skiriama karinio rengimo institucijų istorijai, sistemą paliekant nuošalyje.

Lietuvos karo aviacijos skraidančiojo personalo rengimui skirta istoriografija nèra gausi ir kartu stokoja patikimumo bei empirinio pagrịstumo. Iki šiol išsamiausias tyrimas - 1986 m. išleista Vytenio Statkaus monografiją, kurioje 1919-1940 m. skraidančiojo personalo rengimui skirtas kelių puslapių skyrius ${ }^{4}$. Autorius išskirtinai rèmėsi publikuotais šaltiniais ir egzilyje surinktais Lietuvos kariuomenès karių atsiminimais ${ }^{5}$, todèl knygoje greta neatsakytų klausimų pasitaiko faktinių klaidų. I šios temos tyrimą reikšmingą indèlį įnešè Estela Gruzdienè, kuri savo darbe analizavo 1919-1932 m. skraidančiojo personalo rengimą ${ }^{6}$. Nors autorès tikslas buvo „apžvelgti ir ìvertinti <...> pirmaji ir antraji lakūnu ir žvalgu ugdymo periodą ${ }^{\text {"7 }}$, tačiau ji daugiau sutelkè dèmesț $\mathfrak{i}$ skraidantijji personalą rengusių institucijų kaitos istoriją.

Skraidančiojo personalo rengimo sistemą taip pat šiek tiek aprašè Fe-

2 Pastaba. Oro žvalgas - tai skraidančiajam personalui priskiriamas karys, kuris skrydžių metu žvalgydavo teritoriją, atlikdavo fotografavimo, bombardavimo ir apšaudymo žvalgo kulkosvaidžiu funkcijas, taip pat naviguodavo lèktuvo pilotą. Nuo $1939 \mathrm{~m}$. buvo rengiami $\mathfrak{i}$ dviviečius lèktuvus sodinami oro šauliai, kurie turèdavo atlikti beveik visas anksčiau paminètas funkcijas. Nuo XX a. ketvirtojo dešimtmečio vidurio visi oro žvalgai taip pat privalejo mokèti pilotuoti lèktuvą.

3 Pastaba. Karo aviacijos skraidantysis personalas straipsnyje suvokiamas kaip karo aviacijoje tarnavę karo lakūnai, oro žvalgai ir oro šauliai. Taip pat ị skraidančiojo personalo sudètị ịtraukiami ịvairiose rengimo institucijose studijavę būsimi lakūnai ir oro žvalgai. Pažymètina, kad i skraidančiojo personalo apibrezžtị nepatenka atsargos lakūnai ir oro žvalgai bei atsargai rengiami kariai.

4 Statkus, V. Lietuvos ginkluotos pajégos 1918-1940 m. Chicago, 1986, p. 183-191.

5 Ten pat, p. 5.

6 Gruzdienè, E. Lietuvos karo aviacijos lakūnų ir žvalgų rengimas 1919-1932 m. Karo archyvas, t. XIX, 2004, p. 150-179.

7 Ten pat, p. 151. 
liksas Žigaras ${ }^{8}$ ir Vytautas Lesčius ${ }^{9}$, tačiau šiuose darbuose ji suprantama kaip rengime dalyvavusių institucijų raidos istorija. Enciklopedinio leidinio „Lietuvos kariuomenès karininkai 1918-1953“ X tome pateikti duomenys apie Vytauto Didžiojo karininkų kursų aviacijos skyrių ir jo absolventų sąrašai ${ }^{10}$. Bazinę informaciją apie skraidantijji personalą rengusias institucijas bei rengime dalyvavusius karius taip pat galima rasti Jono Pyragiaus ${ }^{11}$, Algirdo Gamziuko ${ }^{12}$, Gyčio Ramoškos ${ }^{13}$, Eugenijaus Raubicko ${ }^{14}$, Waldemaro Rezmerio ${ }^{15}$ ir kitų autorių darbuose ${ }^{16}$.

Istoriografijoje, kurioje vienu ar kitu aspektu aptariamas skraidančiojo personalo rengimas, gausu pasikartojimų ir kartu klaidingų duomenų atkartojimo. Dalis skraidančiojo personalo rengimui skirtos istoriografijos kelia pagrịstų abejonių dèl jos patikimumo. Algimanto Liekio monografijoje aprašomos skraidantiji personalą rengusios institucijos, taip pat pateikiami fragmentiški duomenys apie pačią rengimo eigą ${ }^{17}$. Vis dèlto išsamioje minètos knygos recenzijoje aviacijos istorikas Saulius Štulas teigia: „Daugybe klaidų bei netikslumų verčia daryti išvada, jog autorius, nors ir ìdejęs daug triūso, nepajègè tinkamai panaudoti surinktos gausios

8 Žigaras, F. Karininkų rengimo ir jų kvalifikacijos kèlimo sistema 1919-1940 m. I dalis. Vilnius, 2018, p. 57-58; Žigaras, F. Karininku rengimo ir jų kvalifikacijos kèlimo sistema 1919-1940 m. II dalis. Vilnius, 2018, p. 33-41, 48-53.

9 Lesčius, V. Lietuvos kariuomene 1918-1920 m. Vilnius, 1998, p. 389-390; Lesčius, V. Lietuvos kariuomenès organizavimo, dislokavimo ir ginkluotès pokyčiai 1938-1940 m. Karo archyvas, t. XXIV, 2009, p. 182-185.

10 Zabielskas, V. (et. al.) Lietuvos kariuomenes karininkai 1918-1953. Vilnius, 2015, p. 298-299, 310, 313, 315.

11 Pyragius, J. (red.) Mūsų sparnai. Lietuvos aviacijos istorija 1919-1929. Kaunas, 1929, p. 27-35.

12 Gamziukas, A. Aviacija Lietuvoje 1919-1940 m. Kaunas, 1993, p. 13-15; Gamziukas, A. Antanas Norèjo Būti Ore. Kaunas, 1997, p. 31-43.

13 Ramoška, G. Lietuvos aviacija. Kaunas, 2009, p. 18-21, 39, 65, 74.

14 Raubickas, E. Ženklas ant munduro. Vilnius, 2005, p. 8-178.

15 Rezmer, W. Litewskie lotnictwo wojskowe 1919-1940. Toruń, 1999.

16 Jonaitis, M. Aspirantų tarnyba: studentiška karo prievolès alternatyva (1926-1940 m.). Kariūnas, Nr. 2 (125), 2015, p. 31-34; Jonaitis, M. Aspirantų tarnyba: studentiška karo prievolès alternatyva (1926-1940 m.). Kariūnas, Nr. 3 (126), 2015, p. 19-23; Rutkiewicz, J., Kulikow, N. W. Wojsko litewskie 1918-1940. Warszawa, 2002, p. 45.

17 Liekis, A. Lietuvos karo aviacija (1919-1940). Vilnius, 1999, p. 139-157, 282-294. 
medžiagos, pervertino savo jëgas bei žinias." ${ }^{18}$ Prie nepatikimos istoriografijos taip pat galima priskirti 2015 m. išleistą Algirdo Ažubalio monografiją ${ }^{19}$. Autorius savo darbe pakartoja ankstesnès istoriografijos žinomus enciklopedinius duomenis, o naujų duomenų patikimumas kelia pagrịstų abejonių ${ }^{20}$. Broniaus Puzinavičiaus darbuose plačiai besiremiant ankstesniais tyrimais ir reportine medžiaga pateikiama trumpa skraidančiojo personalo rengimo apžvalga ${ }^{21}$, kurioje gausu faktinių klaidų ${ }^{22}$.

Istoriografijos apžvalga suponuoja būtinybę revizuoti istoriografijoje itvirtintus teiginius ir ištaisyti pasitaikančius faktologinius netikslumus. Bet pagrindinis šio straipsnio tikslas yra nuosekliai rekonstruoti Lietuvos karo aviacijos 1919-1940 m. skraidančiojo personalo individualią rengimą sistemą, nustatyti jos kaitą (konceptualius pokyčius) ir ịvertinti šios sistemos pakankamumą. Siekiant iškelto tikslo, suformuluoti trys uždaviniai:

18 Štulas, S. Apie A. Liekio knygą „Lietuvos karo aviacija (1919-1940)“ [interaktyvus], 20090203 [žiūrèta 201910 14]. Prieiga per internetą: <http://www.plienosparnai.lt/page. php?318>

19 Ažubalis, A. Matematikos taikymas Lietuvos kariuomeneje 1918-1940 m. Vilnius, 2015, p. 62-63, 97-98.

20 Monografijoje Karo aviacijos mokyklai skirtoje dalyje (p. 62-63) 22 numeriu pažymètoje bibliografineje nuorodoje (p. 63) nukreipiama ị LCVA, f. 1451, ap. 3, b. 114. Pažymètina, kad ši byla neegzistuoja, nes $1966 \mathrm{~m}$. lapkričio 15 d. ị f. 1451, ap. 3 ịrašyta tik 112 bylų. Taip pat tame pačiame monografijos puslapyje 24 numeriu pažymètoje bibliografinèje nuorodoje nukreipiama ị bylą, kurios turinys visiškai nesutampa su knygos tekstu. Autoriaus nurodytojoje byloje (LCVA, f. 1451, ap. 3, b. 33) saugomi 1936 m. instruktorių kursų dokumentai, o tekste kalbama apie Karo aviacijos mokykloje (?) dèstytas disciplinas.

${ }^{21}$ Puzinavičius, B. Karininkas - pedagogas ir vadas (pagal 1921-1940 m. Lietuvos karių spaudos publikacijas). Karo archyvas, t. XXI, 2006, p. 72. Identiško turinio tekstas taip pat publikuotas: Puzinavičius, B. Karininkų rengimo ir kvalifikacijos kèlimo sistema tarpukario nepriklausomoje Lietuvoje (1919-1940 m.), Karinis rengimas ir ugdymas Lietuvoje. Sud. B. Puzinavičius, N. Janulaitienè, 2007, p. 124.

22 Aukštųjų karininkų Didžiojo Lietuvos kunigaikščio Vytauto kursų aviacijos skyrius veiklą pradejjo 1927 m., o ne $1931 \mathrm{~m}$., kaip nurodo autorius. Skirtingai nei teigia dr. B. Puzinavičius, Lietuvos aeroklubas ịsteigtas ne $1936 \mathrm{~m}$., o $1927 \mathrm{~m}$. Straipsnio autorius nurodo, kad „1923 m. vèl buvo surinkta laikina Aviacijos mokykla, sudaryta iš karininkų ir puskarininkių klasių “. Istoriografijoje ir tarp nepublikuotų LCVA saugomų dokumentų patvirtinančių duomenų apie $1923 \mathrm{~m}$. jkurtą „laikiną Aviacijos mokyklą“ aptikti nepavyko. Pažymėtina, kad autorius šiuos teiginius pagrindžiančių informacijos šaltinių nenurodo. Taip pat straipsnyje teigiama, kad visiems 1919 m. Karo aviacijos mokyklą baigusiems puskarininkio laipsniu vèliau suteiktas leitenanto laipsnis, tačiau Mikui Vaicekauskui leitenanto laipsnis nesuteiktas. 
1) i̇vertinti skraidančiojo personalo rengimo sistemoje naudotos atrankos tinkamumą ir efektyvumą;

2) išanalizuoti skraidančiojo personalo rengimo sistemos kaitą, joje naudotas teorinio ir praktinio rengimo programas, priemones ir rengime dalyvavusių karių kompetenciją;

3) nustatyti skraidančiojo personalo rengimo sistemos rezultatus ir ivertinti sistemos atitikti Lietuvos karo aviacijos poreikiams.

Darbo aktualumas grindžiamas siekiu ne tik patikslinti istoriografiją, bet ir pateikti konceptualiai naują požiūrị bei karo aviacijos individualios rengimo sistemos ịvertinimą. I mokslinę apyvartą ịtraukus dar neskelbtus empirinius duomenis bei pasitelkus naują analizès būdą (žr. 1 skyrių) straipsnyje skelbiami rezultatai sudaro galimybes tiksliau įvertinti Lietuvos karo aviacijos ir kartu Lietuvos kariuomenès pasirengimą potencialiam ginkluotam konfliktui. Be to, jame skelbiami tyrimo rezultatai sukuria naujas lyginimo galimybes su kitų valstybių karinèmis oro pajėgomis. Straipsnyje pirmą kartą skelbiami nepublikuoti kiekybiniai duomenys apie parengtų lakūnų ir oro žvalgų skaičių bus aktualūs tęsiant Lietuvos karo istorijos tyrimus.

\section{ANALIZĖS BŪDAS}

V. Statkus, atsižvelgdamas ị karo aviacijos skraidantijji personalą rengusių institucijų kaitą, 1919-1940 m. laikotarpi suskirstė $\mathfrak{i}$ tris etapus:

1. Karo aviacijos mokyklos veiklos laikotarpis (1919 m.).

2. Aviacijos kursų prie karo aviacijos mokomosios eskadrilès ir Vytauto Didžiojo karininkų kursų aviacijos skyriaus veiklos laikotarpis (1921-1932 m.).

3. Naujai suformuotos Karo aviacijos mokyklos veiklos laikotarpis $\left(1932^{23}-1940 \text { m. }\right)^{24}$.

${ }^{23}$ Pastaba. V. Statkus naujo etapo pradžia pasirenka naujai suformuotos Karo aviacijos mokyklos veiklos pradžią, tačiau nurodo netikslią jos įkūrimo datą. Karo aviacijos mokykla buvo įsteigta ne 1936 m., kaip nurodo V. Statkus, o 1932 m. Paskutinio, trečiojo, etapo pradžios data patikslinta vèlesniuose tyrimuose, pavyzdžiui: Gruzdienè, E. Lietuvos karo aviacijos lakūnų ir žvalgų rengimas 1919-1932 m. Karo archyvas, t. XIX, 2004, p. 151.

24 Statkus, V. Lietuvos ginkluotos pajègos 1918-1940 m. Chicago, 1986, p. 183-185. 
Istoriografijos apžvalgoje visuose aptartuose tyrimuose be išimties laikomasi V. Statkaus pasiūlyto Lietuvos karo aviacijos skraidančiojo personalo rengimo periodizavimo. Vis dèlto šis istoriografijoje ịsitvirtinęs periodizavimas yra kritikuotinas dèl kelių netikslių išankstinių prielaidų. Visų pirma toks skirstymas, remiantis vieninteliu kriterijumi (rengime dalyvavusių institucijų kaita), nuteikia, kad kitų periodizavimui svarbių kriterijų nèra. Nè viename ankstesniame tyrime šios prielaidos nebandoma empiriškai pagrịsti. Taip pat pasirinktas periodizavimas leidžia manyti, kad skraidančiojo personalo rengimo sistema priklausė nuo institucijų, o ne atvirkščiai - institucijų kaitą lèmẻ konceptualūs pokyčiai rengimo sistemoje. Periodizavimas remiantis skraidantijj personalą rengusių institucijų kaita yra ydingas, nes istoriografijoje leido įsitvirtinti nepagrịstai siauram rengimo sistemos apibrežimui. Todèl jị naudoję autoriai, analizuodami skraidančiojo personalo rengimo sistemą, buvo susitelkę tik ̣̇ rengime dalyvavusių institucijų istoriją, o kitos neatskiriamos rengimo sistemos sudedamosios dalys liko paraštese. Galima teigti, kad V. Statkaus pasiūlytas ir kitų autorių plačiai taikytas periodizavimas vienareikšmiškai labiau tinka skraidančiojo personalo rengime dalyvavusių institucijų raidos istorijai analizuoti, nei leidžia suprasti ir paaiškinti pačią 1919-1940 m. skraidančiojo personalo rengimo sistemą.

Karinių specialistų rengimo sistemą sudaro trys pagrindinès sudedamosios dalys, iš kurių pirmoji - atranka. Jos metu pagal iš anksto nustatytus kriterijus atrenkami konkrečiai karinei specialybei labiausiai tinkantys kariai. Jeigu prieš pradedant karinị rengimą nèra organizuojama atranka, tai leidžia manyti, kad rengimas vyks nerezultatyviai. Labai tiketina, kad bus priimti konkrečiai karinei specialybei netinkantys kariai, kurie pasitrauks ar bus pašalinti jau vykstant kariniam rengimui. Taip pat jeigu organizuojama atranka yra neišsami ir nenuosekli arba jos iš viso nèra, galima teigti, kad karinio rengimo sistema neišbaigta.

Antroji sudedamoji dalis - i pakopas suskirstyta nuosekli rengimo eiga, kuri turi aiškiai apibrèžtą siektiną rezultatą. Dažniausiai karinis rengimas skirstomas į keletą pakopų, iš kurių pirmoji skirta bazinèms žinioms suteikti ir pradiniams ịgūdžiams suformuoti. Tuo tarpu tolesnès pakopos skirtos jau ịgytų žinių ir ịgūdžių tobulinimui, sudètingesnèms ir labiau specializuotoms žinioms suteikti. Visos rengimo pakopos orientuotos ị galutinị karinio rengimo sistemos rezultatą - aiškiai apibrežtą konkrečių žinių ir igūdžių rinkinị (kvalifikaciją), kuris leistų kariniam 
specialistui ịvykdyti jam skirtas užduotis.

Kompleksiškiausia dalis - rengimo turinys, kuris apibrèžiamas programose. Rengimo sistemos kertine ašimi galima laikyti programą, kuri nulemia visus tolesnius veiksmus. Tai leidžia manyti, kad ne toks efektyvus bus rengimas, kuris neturi aiškios programos. Su rengimo programa tiesiogiai susijusios rengime naudojamos priemonès. Trūkstant individualaus kovinio rengimo programos igyvendinimui reikalingu priemonių, galima manyti, kad ir visa rengimo sistema nebus pakankamai rezultatyvi ir efektyvi. Dažniausiai rengimo programas igyvendina instruktoriai, pasitelkdami mokymo priemones. Šių smulkesnių, tačiau savo reikšme ne mažiau svarbių elementų kaita signalizuoja reikšmingus rengimo sistemos pokyčius.

Kiekviena minètų rengimo sistemos sudedamųjų dalių yra šio straipsnio analizès pjūviai tiriant 1919-1940 m. Lietuvos karo aviacijos skraidančiojo personalo individualaus rengimo sistemą. Tolesniuose straipsnio skyriuose analizuojama atrankos sistema ir kriterijai, rengimo pakopos ir rengimo programos, ịvardyti jas iggyvendinę kariai bei naudotos priemonés.

\section{ATRANKOS SISTEMA: PUSIAUSVYROS PAIEŠKOS TARP NORINČIŲJŲ IR GALINČIŲJŲ MOKYTIS}

Karo aviacijos mokyklos pirmasis viršininkas Konstantinas Fugalevičus 1919 m. atrinkdamas karius daugiausia rèmèsi savo asmeniniu vertinimu, todèl ị mokyklą buvo priimami visų pirma joje norintys, bet nebūtinai galintys studijuoti kariai ${ }^{25}$. Siekiant įvertinti kario galimybes studijuoti Karo aviacijos mokykloje, buvo numatyti formalūs kriterijai išsilavinimo cenzas ir sveikatos būklè. Visgi ị šiuos du kriterijus žiūrèta atsainiai - priimtų i Karo aviacijos mokyklą karių išsilavinimas buvo labai ịvairus, kai kurie jų neturèjo net pradinị išsilavinimą pagrindžiančių dokumentų. Prasidejjus sudètingesniems užsièmimams, karių nepakan-

25 Stanaitis, S. Lietuvos savanorio-kūrèjo, karo lakūno, Karo invalidu sajungos pirmininko, šachmatu rinktinès kapitono, Gulago kalinio likimo vingiai. Kaunas, 1992, p. 24-28; Peseckas, L. Karo lakūno pasakojimai. Kaunas, 2006, p. 14-15. 
kamas pasiruošimas greitai išryškẻjo, tačiau buvo nuspęsta jų iš mokyklos nešalinti ${ }^{26}$. Praejus beveik mènesiui nuo studiju pradžios, pradèta tikrinti sveikatos būklę, o penktadalio karių sveikata patikrinta tik studijoms ịpusèjus. Iš $48^{27}$ ị mokyklą priimtų karių tik du dẻl sveikatos būklès netiko tarnybai aviacijoje, todèl buvo pašalinti ${ }^{28}$. Prièmimas i Karo aviacijos mokyklą vyko labai chaotiškai ir tęsèsi neproporcingai ilgai. Mokykla veike 10 mènesių, o paskutinis karys ị ją buvo priimtas praejjus beveik penkiems ménesiams nuo mokyklos veiklos pradžios ${ }^{29}$.

Po ypač trumpos tarnybos iš Lietuvos karo aviacijos savo noru pasitraukè didelè Karo aviacijos mokyklos absolventų dalis. 1919 m. gruodžio $16 \mathrm{~d}$. Karo aviacijos mokyklą baigè 34 iš 48 (arba 71 proc.) priimtu karių, ir jie visi buvo paskirti $\mathfrak{i}$ karo aviaciją. Nepraejus ne metams, iš karo aviacijos pasitraukè 9 iš 34 absolventų, o praejus trejiems metams po mokyklos baigimo 17 (arba 50 proc.) absolventų joje nebetarnavo. Dar svarbiau, jog, pasibaigus Nepriklausomybès karui, 44 proc. mokyklos absolventų ejo pareigas, nesusijusias su lakūno ar oro žvalgo tarnyba ${ }^{30}$. Galima teigti, kad 1919 m. skraidančiojo personalo atranka buvo minimali, paviršutiniška ir neefektyvi.

Atrankos sistema patobulinta vietoje 1919 m. gruodžio 18 d. uždarytos

${ }^{26}$ Laurinaitis, J., M. Karo aviacijos mokyklą prisimenant. Karo archyvas, t. 1, 1925, p. $178-191$.

${ }^{27}$ Pastaba. Istoriografijoje ị Karo aviacijos mokyklą priimtų mokinių skaičius ịvairuoja, tačiau atliekant tyrimą, išanalizavus Karo aviacijos mokyklos įsakymus (LCVA, f. 1451, ap. 3, b. 1, l. 1-95), nustatyta, kad ị mokyklą buvo priimti 48 mokiniai. Skirtingai nei teigia Jonas Pyragius, Karo aviacijos mokykloje niekada nesimoke Suchoverskis ir Kanapinskas (Pyragius, J. (red.) Mūsu sparnai. Lietuvos aviacijos istorija 1919-1929. Kaunas, 1929, p. 27). 1919 m. kovo 12 d. Karo aviacijos mokyklos isakyme Nr. 1 klaidingai i mokinių sąrašą įrašytas karininkas Eugenijus Šalkauskas, kuris šioje mokykloje tarnavo instruktoriumi ir dèstè taktiką bei statutus.

${ }^{28}$ Karo aviacijos mokyklos įsakymas Nr. 23, 1919 m. balandžio 3 d. LCVA, f. 1451, ap. 3, b. 1, 1. 10; Karo aviacijos mokyklos įsakymas Nr. 141, 1919 m. liepos 30 d. LCVA, f. 1451, ap. 3, b. 1, l. 48. Karo aviacijos mokyklos ịsakymas Nr. 151, 1919 m. rugpjūčio 9 d. LCVA, f. 1451 , ap. 3, b. 1, 1. 51 .

29 Karo aviacijos mokyklos ịsakymas Nr. 150, 1919 m. rugpjūčio 8 d. LCVA, f. 1451, ap. 3, b. 1, 1. 51 .

30 „Lietuvos kariuomenes karininkai 1918-1953“, II-VIII t., pateiktos Karo aviacijos mokyklos absolventų biografijos. 
Karo aviacijos mokyklos ${ }^{31} 1921 \mathrm{~m}$. skraidančio personalo rengimui ịsteigus nereguliarius kursus prie Mokomosios eskadrilès. Siekiant ivvertinti karių tinkamumą tarnybai karo aviacijoje, nuo $1921 \mathrm{~m}$. greta atrankos kriterijų pradètas taikyti naujas atrankos mechanizmas. Iki kursų pradžios visi potencialūs kursų klausytojai atvykdavo ị karo aviaciją, kur po sveikatos patikrinimo atlikdavo bandomuosius skrydžius ${ }^{32}$. Šių skrydžių metu buvo siekiama ịvertinti karių fizinę ištvermę, orientavimosi erdvėje igūdžius ir savitvardą kritinèse situacijose. Pavyzdžiui, $1921 \mathrm{~m}$. sausiovasario mèn. ił karo aviaciją atvyko 9 leitenantai, iš jų 4 po bandomųjų skrydžių kaip netinkami tarnybai aviacijoje buvo grąžint i savo dalinius ${ }^{33}$.

1922-1923 m. susiformavo atrankos sistema, kurią sudare bandomasis skrydis ir atrankos kriterijai. Pastarieji minimaliai buvo keičiami ir labiausiai priklausè nuo pretendento karinio laipsnio ${ }^{34}$. XX a. trečiajame dešimtmetyje ị kursus galëjo pretenduoti ne vyresni nei 28 metų, tinkamos sveikatos būklès ir tarnyboje teigiamai atestuoti jaunesnieji karininkai (ltn. ir vyr. ltn.), kurie iki kursų buvo igiję ne žemesnį nei 8 gimnazijos klasių išsilavinimą ${ }^{35}$. Šiuo laikotarpiu ypatingas dėmesys buvo skiriamas kandidato matematikos žinioms ${ }^{36}$. Atrankos kriterijai karininkams reikšmingai nepasikeitè ir ketvirtajame XX a. dešimtmetyje $e^{37}$. I kursus buvo priimami tinkamos sveikatos būklès, ne vyresni nei 26 metų, j. ltn. arba ltn. laipsnị turintys, baigę aukštesniąją mokyklą ir tarnyboje teigiamai atestuoti $^{38}$. Pažymètina, kad nuo $1922 \mathrm{~m}$. pradètas didinti išsilavinimo cenzas norintiems studijuoti Karo mokykloje, o nuo 1928 m. ì ją galejo

31 Karo aviacijos mokyklos įsakymas Nr. 271, 1919 m. gruodžio 18 d. LCVA, f. 1451, ap. 3, b. 1, 1. 95 .

32 Mikènas, J. Gyvenimo skrydis. Kaunas, 1994, p. 30.

33 Isakymas oro laivynui Nr. 5-18, 1921 m. sausio 12 d.-kovo 14 d. LCVA, f. 1323, ap. 1, b. $21,1.5-18$.

34 Gustaitis, A. Lakūnų ir žvalgų mokymas mūsų aviacijoje. Kardas, Nr. 14, 1925, p. 10-12.

35 Gruzdienè, E. Lietuvos karo aviacijos lakūnų ir žvalgų rengimas 1919-1932 m. Karo archyvas, t. XIX, 2004, p. 169-170.

36 Ažubalis, A. Matematikos taikymas Lietuvos kariuomeneje 1918-1940 m. Vilnius, 2015, p. 90.

37 Vaičeliūnas, J. Tëvynès sargyboje. Sudbury, 1955, p. 56-57.

38 Kariuomenès štabo 1936 m. liepos 4 d. aplinkraštis Nr. 7. LCVA, f. 1451, ap. 3, b. 25, 1. 24 . 
stoti tik gimnazijų absolventai ${ }^{39}$. Dèl šios priežasties išsilavinimo cenzas trečiojo dešimtmečio pabaigoje atrenkant karius tarnybai Karo aviacijoje prarado aktualumą.

Kaip ir 1919 m., $\mathfrak{i}$ atrankos kriterijus karo aviacijos vadovybė (visu pirma aviacijos viršininkas gen. ltn. Juozas Kraucevičius) 1921-1926 m. žiūrèjo gana paviršutiniškai. I kursus buvo priimami kariai, vyresni, nei numatyta reikalavimuose ${ }^{40}$, galimai neturintys Lietuvos pilietybès ${ }^{41}$ ar reikalaujamo išsilavinimo ${ }^{42}$, taip pat pakartotinai priimti iš jų jau pašalinti ${ }^{43}$ ar su karo aviacijos vadovybe giminystès bei kitais socialiais ryšiais susiję kariai ${ }^{44}$. Atsainus požiūris ị atranką turejjo reikšmès kursų klausytojų studijų rezultatams - jie buvo blogi. Pavyzdžiui, 1921-1923 m. dažnai kursų klausytojai keletą kartų perlaikydavo egzaminus ar išklausydavo atskirų disciplinų kursus, neretai dèl prastų studijų rezultatų jiems nebuvo leidžiama mokytis skraidyti ${ }^{45}$.

Nuo 1927 m. atrankos kriterijais vadovautasi pastebimai griežčiau ir dèl to šiek tiek sumažèjo priimtų, bet kursus nebaigusių karių. Pavyz-

39 Knezys, S. Lietuvos kariuomenès karo mokykla 1919-1940 metais. In. Lietuvos kariuomenés karininkai 1918-1953. II tomas. Sud. B. Kulnyte. Vilnius, 2002, p. 348-349.

40 Isakymas aviacijai Nr. 9, 1926 m. sausio 23 d. LCVA, f. 1323, ap. 1, b. 132, 1. 9; 1-os oro eskadrilès oro žvalgo plk. Egerto Oskaro skraidymo knygelè. LCVA, f. 531, ap. 1, b. 326, 1. $1-2$.

41 Isakymas Aviacijos daliai Nr. 6, 1920 m. rugsejjo 11 d. LCVA, f. 1323, ap. 1, b. 13, 1. 471; Isakymas Aviacijos daliai Nr. 11, 1920 m. rugsejjo 16 d. LCVA, f. 1323, ap. 1, b. 13, 1. 476. 42 Vilniaus miesto ir apskrities karo komendantūros 1 tn. Prano Stelmoko tarnybos lapas, 1921 m. sausio 30 d. LCVA, f. 930, ap. 2S, b. 236, 1. 1-3; Lukšys, S., Mintautas, R., Monkevičius, J., Palūžę sparnai. Vilnius, 1997, p. 23-27; 2-os eskadrilès vyr. psk. Antano Kielos tarnybos lapas. LCVA, f. 930, ap. 7, b. 5811, 1. 82-83; 3-ios eskadrilès jaun. ltn. Grigoriaus Heidrikio tarnybos lapas. $L C V A$, f. 930, ap. 2H, b. 9, 1. 2; Žinios apie jaun. ltn. Grigorių Heidriki. LCVA, f. 930, ap. 2H, b. 9, 1. 50.

43 3-ios oro eskadrilès karo lakūno kpt. Jono Nastaro tarnybos lapas. LCVA, f. 930, ap. 5, b. $1921,1.14$.

44 Žinios apie e. p. karo lakūną vyr. psk. Borisą Kraucevičių. LCVA, f. 930. ap. 8, b. 48, 1. 64; Stanaitis, S. Lietuvos savanorio-kūrèjo, karo lakūno, Karo invalidu sajungos pirmininko, šachmatu rinktinés kapitono, Gulago kalinio likimo vingiai. Kaunas, 1992, p. 51.

45 Isakymas aviacijai Nr. 18, 1921 m. kovo 14 d., LCVA, f. 1323, ap. 1, b. 21, 1. 18; Isakymas aviacijai Nr. 57, 1921 m. lapkričio 1 d., $L C V A$, f. 1323, ap. 1, b. 21, 1. 56; Isakymas aviacijai Nr. 46, 1922 m. rugsèjo 25 d. LCVA, f. 1323, a p. 1, b. 44, 1. 49; Isakymas aviacijai Nr. 51, 1925 m. birželio 27 d., LCVA, f. 1323, ap. 1, b. 115, 1. 61. 
džiui, 1936-1937 m. iš 22 priimtų karininkų kursus baigè 15, o trečdalis kursų klausytojų (7 iš 22) buvo pašalinti dèl drausmès pažeidimų ${ }^{46}$.

Pirmąji Lietuvos karo aviacijos dešimtmetị atrankos sistema ir jos kriterijai puskarininkiams ir kareiviams reikšmingai nesiskyrè nuo karininkų atrankos sistemos ir jiems keltų kriterijų. 1921-1926 m. ํ kursus prie Mokomosios eskadrilès galèjo būti priimti ne vyresni nei 28 metų, ne žemesnị nei 6 gimnazijos klasių išsilavinimą ${ }^{47}$ igiję puskarininkiai ir kareiviai, pažadeję, baigę kursus, ne mažiau kaip dvejus metus ištarnauti karo aviacijoje ${ }^{48}$. I $1929 \mathrm{~m}$. organizuotus specialius puskarininkiams skirtus kursus buvo priimami tinkamos sveikatos, ne vyresni nei 25 metu vyrai, išlaikę matematikos ir lietuvių kalbos egzaminus. Kareiviai, igiję 6 klasių ar aukštesnị išsilavinimą, buvo priimami be egzaminų ${ }^{49}$.

Puskarininkių atrankos sistema buvo pakeista 1932 m., įsteigus naują Karo aviacijos mokyklą. 1932-1940 m. atranka ị Karo aviacijos mokyklos puskarininkių klasę buvo suskirstyta į du etapus. Pirminę atranką vykdè apskričių komendantai - jie patikrindavo kandidato dokumentus, surinkdavo ji apibūdinančią informaciją (pavyzdžiui, apie priklausomybę organizacijoms, politines pažiūras), o komendantūros gydytojas atlikdavo pirminị sveikatos patikrinimą ${ }^{50}$. Antrasis etapas vykdavo kandidatams atvykus ị karo aviaciją, kur didžiausias demesys buvo skiriamas sveikatos būklès įvertinimui ${ }^{51}$.

I Karo aviacijos mokyklą galejo stoti neteisti ir teismo nepersekiojami 18-20 m. Lietuvos piliečiai, baigę ne mažiau nei 4 aukštesniosios mokyklos klases ir tinkami tarnybai aviacijoje ${ }^{52}$. Šiais atrankos kriterijais buvo vadovaujamasi priimant i pirmąsias tris Karo aviacijos mokyklos

\footnotetext{
46 Navaitis, A. Šimtmečio skrydis. Karo lakūno atsiminimai. Vilnius, 2017, p. 54.

47 Gruzdienė, E. Lietuvos karo aviacijos lakūnų ir žvalgų rengimas 1919-1932 m. Karo archyvas, t. XIX, 2004, p. 169-170.

48 Isakymas aviacijai Nr. 3, 1922 m. sausio 27 d. LCVA, f. 1323, ap. 1, b. 44, 1. 3.

49 İsteigta puskarininkių lakūnų mokykla. Karys, 3(503), 1929, p. 49.

50 Plačiau žr.: 1934 m. ̣̇ Aviacijos puskarininkių lakūnų ir mechanikų mokyklos lakūnų skyrių parinktų mokinių-kandidatų sąrašai ir charakteristikos. LCVA, f. 1323, ap. 1, 301, 1. 33-75.

51 Mikutis, A. Lietuvos karo aviacijos tarnyboje 1936-1940. Plieno sparnai, Nr. 1, 1992, p. 22.

52 Aviacijos puskarininkių mokyklos statutas. Vyriausybès žinios, 1932, balandžio 9, Nr. 381 (2626), p. 4.
} 
laidas. Dèl palyginti žemo išsilavinimo cenzo ir nepakankamų matematikos žinių 1932-1935 m. kildavo sunkumų studijuojant teorines aviacijos disciplinas ${ }^{53}$. Atsižvelgiant ị pastebètus trūkumus $1936 \mathrm{~m}$. atrankos kriterijai minimaliai pakeisti numatant, kad ị mokyklą gali stoti progimnaziją baigę ar igiję jai tolygų išsilavinimą kariai. Taip pat šiek tiek padidintas amžiaus cenzas (18-24 m.) bei ịvestas šeiminès padèties apribojimas - $\mathfrak{i}$ mokyklą galëjo stoti tik nevedę vyrai ${ }^{54}$.

Puskarininkiams taikyta atrankos sistema ir kriterijai užtikrindavo gana žemą ị Karo aviacijos mokyklą priimtų ir ją baigusių karių santykị. Pavyzdžiui, $1932 \mathrm{~m}$. ị mokyklą buvo priimti 48 kariai ${ }^{55}$, iš jų 23 baige studijas. ${ }^{56}$ Visgi tik 12 absolventų buvo laikomi tinkamais tęsti tarnybą karo aviacijoje $^{57}$. $1934 \mathrm{~m}$. ị ją iš ịvairių komendantūrų atvyko 56 kandidatai $^{58}$, iš jų po sveikatos patikrinimo į mokyklą priimti $26^{59}$, o ją baigè $14^{60}$. Visi tęsè tarnybą Lietuvos karo aviacijoje ir vykdè lakūnų funkcijas iki Sovietų Sajungos okupacijos. 1935 m. lapkričio mèn. Karo aviacijos mokyklos puskarininkių klasès lakūnų skyriuje pradejjo studijuoti 49 lakūnai ${ }^{61}$, iš jų mokyklą baigè ir karo lakūno vardas buvo suteiktas 20 absolventų $^{62}$.

${ }^{53}$ Karo aviacijos mokyklos viršininko 1933 m. sausio 10 d. raštas Nr. 27 aviacijos viršininkui. LCVA, f. 1451, ap. 3, b. 6, 1. 3. Pyragius, J. Lietuvos karo aviacijos tarnyboje. Plieno sparnai, Nr. 5, p. 1998, p. 57.

${ }^{54}$ Karo aviacijos puskarininkiams lakūnams ir mechanikams ruošti įstatymas. Vyriausybès žinios, 1936, spalio 22, Nr. 555 (3855), p. 4-5.

55 Aviacijos štabo Puskarininkių lakūnų mokyklos mokinių abėcèlinè knyga. LCVA, f. 930 , ap. 7, b. $4439,1.1-200$.

${ }^{56}$ Karo aviacijos iqsakymas Nr. 255, 1934 m. spalio 31 d. LCVA, f. 1323, ap. 1, b. 292, 1. 321.

${ }^{57}$ Karo aviacijos viršininko raportas Nr. 737/sl, 1934 m. spalio 31 d. LCVA, f. 1323, ap. 1, 301, 1. 25.

${ }^{58}$ Karo aviacijos įsakymas Nr. 271, 1934 m. lapkričio 19 d. LCVA, f. 1323, ap. 1, b. 292, 1. 341 .

${ }^{59}$ Karo aviacijos įsakymas Nr. 280, 1934 m. lapkričio 28 d. LCVA, f. 1323, ap. 1, b. 292, 1. 352 .

${ }^{60}$ Karo aviacijos įsakymas Nr. 82, 1937 m. spalio 30 d. LCVA, f. 1323, ap. 1, b. 396, 1. 110.

${ }^{61}$ Lakūnų skyriaus klasės žurnalas. 1936-1937 m. LCVA, f. 1451, ap. 3, b. 30, 1. 5-6.

${ }^{62}$ Kariuomenès vado ịsakymas Nr. 24, 1938 m. lapkričio 7 d.; Kariuomenès vado ịsakymas Nr. 20, 1939 m. birželio 1 d.; Kariuomenès vado ịsakymas Nr. 3, 1938 m. vasario 15 d., <www.epaveldas.lt> 
1938 m. 37 kariai buvo priimti i Karo aviacijos mokyklos puskarininkių klasę ${ }^{63}$ o ją baigè $14^{64}$. Dauguma Karo aviacijos mokyklos nebaigdavo dèl nepakankamų gabumų - neišskrisdavo savarankiškai arba neišlaikydavo teorinių disciplinų egzaminų. Taip pat dalis buvo pašalinti dèl drausmès, keli žuvo per skraidymo pratybas ${ }^{65}$.

Remiantis užsienio šalių patirtimi, XX a. trečiojo dešimtmečio antrojoje pusejje Lietuvos karo aviacijoje lèktuvų apgadinimu ar karių žūtimi pasibaige ìvykiai pradèti sieti su skraidančiojo personalo fizine būkle ${ }^{66}$. Kiek vèliau spaudoje pradèta diskutuoti ne vien apie fizinès, bet ir apie psichologinès būklès įtaką skrydžiams ${ }^{67}$. Todèl 1927-1928 m. prie Karo aviacijos medicinos punkto pradèta kurti aviacijos medicinos laboratorija ir atrankoje pradèti naudoti prietaisai psichomotorinėms reakcijoms tirti $^{68}$. Nuo trečiojo dešimtmečio pabaigos pagrindiniu atrankos kriterijumi tapo nuodugnus, $\mathfrak{i}$ keletą etapų suskirstytas sveikatos būklès patikrinimas. Taip pat reikalavimai sveikatos būklei buvo universalus atrankos kriterijus, taikomas karininkams ir kareiviams. Apie savaitę trunkančio tikrinimo metu įvairiuose Karo ligoninès skyriuose buvo tiriama kandidato fizinè būklè, ypač regejjimas. Vèliau naudojant Karo aviacijos medicinos laboratorijoje esančius specializuotus prietaisus buvo tiriami kandidato pusiausvyros organai, psichomotorinių reakcijų eiga, gebejimas tiksliai skirti spalvas ir nustatyti atstumus ${ }^{69}$.

63 Karo aviacijos mokyklos kpt. Juozo Selioko 1938 m. gegužès d. 30 raportas Nr. 9 Mokomosios grupès vadui. LCVA, f. 1451, ap. 3, b. 54, 1. 43-44.

64 Isakymas Karo aviacijai Nr. 88, 1940 m. spalio 15 d. LCVA, f. 1323, ap. 1, b. 594, 1. 23.

65 Aviacijos štabo Puskarininkių lakūnų mokyklos mokinių abėcèlinė knyga. LCVA, f. 930, ap. 7, b. 4439, 1. 108-109; 7-os eskadrilès skaidymo žurnalas 1938-1940 m. LCVA, f. 531, ap. 1, b. 198, 1. 7-8; Žinios apie Karo aviacijos mokyklos nelaimingų atsitikimų ir lèktuvų palaužimus 1937 m. LCVA, f. 1451, ap. 3, b. 79, 1. 1; II laidos mokinių lakūnų abėcèlinè knyga. LCVA, f. 930, ap. 7, b. 5005, 1. 105-107.

66 Barkauskas, S. Medicinos tarnyba aviacijoje ir aviacijos gydytojas. Mūsǔ žinynas, Nr. 29, 1926, p. 283-288.

67 Vaivada, B. Lakūnų psichotechnika. Mūsų žinynas, Nr. 73, 1931, p. 241-253.

68 Tupčiauskas, V. Lakūnų mediciniškas parinkimas ir jų sveikatos kontrolè. Lietuvos sparnai, 1934, balandis, Nr. 4 p. 92-94.

69 Statkus, V. Lietuvos ginkluotos pajégos 1918-1940 m. Chicago, 1986, p. 245-246. 
Nuo XX a. trečiojo dešimtmečio pabaigos atrankose dalyvavę kariškiai savo atsiminimuose kaip svarbiausią atrankos kriterijų išskyrè ypač precizišką ir ilgai trukusị sveikatos būklès tikrinimą ${ }^{70}$. Ltn. Stasys Baipšys apie 1931 m. vykusią atranką rašè: „Mažiausias koks niekniekis fizinèje struktūroje ar dvasinio komplekso nepilnas išsivystymas ir jau: "netinkamas. "71 1932 m. į Karo aviacijos mokyklą ịstojęs eil. Juozas Pyragius savo atsiminimuose teigè, kad po sveikatos patikrinimo iš maždaug 150 buvo atrinkti 48 kariai, tinkami tapti lakūnais ${ }^{72}$. Po kelerių metų, 1936 m. rugsejjo mèn., Karo aviacijos mokykloje mokytis pradèjęs j. ltn. Antanas Navaitis, prisimindamas atranką, akcentavo sveikatos būklès patikrinimą: „Ypač kruopščiai Karo ligoninejje tikrinta būsimuju karo lakūnų sveikata. Iš daugiau kaip 60 sveiku Karo mokyklos patikrintų vyru aviacijos tarnybai tinkamu atrinko vos $22 .{ }^{\text {"73 }}$

\section{SKRAIDANČIOJO PERSONALO RENGIMO SISTEMOS KAITA}

\subsection{Dviejų pakopų rengimo sistema (1919-1928 m.)}

1919-1928 m. skraidančiojo personalo rengimą galima suskirstyti i dvi pakopas: iš jų pirmoji apima pradinị teorinị ir praktinị rengimą, o antroji buvo skirta tolesniam praktinių igūdžių tobulinimui. 1919-1928 m. ypač dažnai keitèsi institucijos, vykdančios skraidančiojo personalo pradinị teorinị ir praktinị rengimą (žr. 9 lentelę). 1919 m. jis vyko Karo aviacijos mokykloje, 1921-1925 m. - Mokomosios eskadrilès aviacijos

\footnotetext{
70 Vaičeliūnas, J. Tẻvynès sargyboje. Sudbury, 1955, p. 56-57, 60-61; Baipšys, S. Nuotykiai padangèje ir žemèje. Kaunas, 1995, p. 6-11; Mikutis, A. Lietuvos karo aviacijos tarnyboje 1936-1940. Plieno sparnai, Nr. 1, 1992, p. 22.

71 Baipšys, S. Nuotykiai padangèje ir žemèje. Kaunas, 1995, p. 6.

72 Pyragius, J. Lietuvos karo aviacijos tarnyboje. Plieno sparnai, Nr. 5, p. 1998, p. 56.

73 Navaitis, A. Šimtmečio skrydis. Karo lakūno atsiminimai. Vilnius, 2017, p. 49.
} 
kursuose $^{74}$, o 1926-1928 m. - Vytauto Didžiojo karininkų kursų aviacijos skyriuje $^{75}$. Laikina pradinio teorinio rengimo išimtimi galima laikyti dvi Karo mokyklos laidas, kurių absolventai igijo minimalų teorini parengimą iki paskyrimo ị karo aviaciją. $1920 \mathrm{~m}$. lapkričio mèn. formuojant Karo mokyklos IV laidą buvo pakeisti mokymo planai ir numatyta pradèti rengti ìvairių, tarp jų ir aviacijos, specialybių karininkus ${ }^{76}$. IV laidos Karo mokyklos kariūnai $1921 \mathrm{~m}$. liepos mèn., likus penkiems mènesiams iki studijų pabaigos, buvo suskirstyti i grupes, iš kurių viena ịvardyta kaip aviacijos grupe $\dot{e}^{77}$. Šios grupès kariūnams buvo suteiktas minimalus teorinis parengimas, baigę Karo mokyklą, jie buvo paskirti ị karo aviaciją ${ }^{78}$. Labai panašiai buvo rengiant Karo mokyklos V laidą - 1923 m. rugsejjo 4 d., likus ménesiui iki studijų pabaigos, suformuota aviacijos kariūnų grupe $^{79}$, jos 12 absolventų buvo paskirti ị karo aviaciją ${ }^{80}$.

Vis dèlto 1919-1928 m. instituciniai pokyčiai neturèjo lemiamos ịtakos teorinio rengimo programai, nes keičiantis institucijoms jos sudètis kito nežymiai. 1919 m. Karo aviacijos mokykloje buvo sudarytos dvi savo apimtimi besiskiriančios teorinio rengimo programos. Abiejų programų daugiau kaip trečdalị sudarè bazinès karo mokslo ir bendrojo išsilavinimo disciplinos. Likę du trečdaliai buvo skirti pagrindinèms aviacijos disciplinoms ${ }^{81}$, kurios išskaidytos i gana smulkias ir šiek tiek „persidengiančias“

74 Pastaba. Karo aviacijos 1921-1925 m. dokumentuose prie Mokomosios eskadrilès organizuotų kursų pavadinimai labai ịvairuoja (kursai, aviacijos kursai, karininkų mokslo klasė, aviacijos karininkų kursai, teoriniai kursai ir pan.). Straipsnyje pasirinktas dažniausiai nepublikuotuose šaltiniuose naudotas pavadinimas - aviacijos kursai.

75 Pastaba. 1925-1932 m. keletą kartų keitèsi Vytauto Didžiojo karininkų kursų ir kartu jų sudettyje veikusių aviacijos kursų pavadinimas. Straipsnyje pasirinktas paskutinysis ir nepublikuotuose šaltiniuose dažniausiai naudotas pavadinimas.

76 Knezys, S. Lietuvos kariuomenès karo mokykla 1919-1940 metais. In. Lietuvos kariuomenés karininkai 1918-1953. II tomas. Sud. B. Kulnytė. Vilnius, 2002, p. 348-349.

77 Ltn. Kazio Zakšausko tarnybos lapas, 1923 m. sausio 23 d. LCVA, f. 930, ap. 2Z, b. 15, 1. 2.

78 Isakymas aviacijai Nr. 69, 1921 m. gruodžio 30 d. LCVA, f. 1323, ap. 1. b. 21, l. 68.

79 Mokomosios oro eskadrilès ltn. Kazio Mailos tarnybos lapas, 1923 m. lapkričio 8 d. LCVA, f. 930, ap. 2M, b. 19, 1. 1-2.

${ }^{80}$ İsakymas aviacijai Nr. 96, 1923 m. lapkričio 8 d. LCVA, f. 1323, ap. 1, b. 67, 1. 45.

81 Pastaba. Programose numatyti kai kurių disciplinų praktiniai užsièmimai. 
dalis ${ }^{82}$. Lyginant šias dvi programas su perskaitytų paskaitų duomenimis galima teigti, kad nė viena iš jų nebuvo nuosekliai igyvendinta ${ }^{83}$.

$1921 \mathrm{~m}$. organizavus Mokomosios eskadrilès aviacijos kursus buvo patvirtinta nauja skraidančiojo personalo teorinio rengimo programa ${ }^{84}$. Ši programa, palyginti su 1919 m. programa, buvo daug glaustesnè ir labiau orientuota į specialiąsias aviacijos disciplinas. Antrą kartą organizuojant Mokomosios eskadriles aviacijos kursus buvo patvirtinta 330 val. trukmés atnaujinta skraidančiojo personalo pradinio teorinio rengimo programa. Tobulinat programą anksčiau kaip atskiros dèstytos disciplinos naujojoje programoje buvo sujungtos. Taip pat atliepiant karo aviacijai skirtas užduotis buvo ịvesta nauja disciplina - artilerijos ugnies koregavimas $^{85}$. Iš esmès nekeičiant dèstytų disciplinų sudèties $1921 \mathrm{~m}$. patvirtinta teorinio rengimo programa buvo igyvendinama visuose iki 1926 m. Mokomosios eskadrilès aviacijos kursuose ${ }^{86}$ ir Vytauto Didžiojo karininkų kursų aviacijos skyriuje ${ }^{87}$.

Atliekant tyrimą nepavyko rasti išsamesnių duomenų apie pradinio teorinio rengimo programos turinị. Nepublikuotuose šaltiniuose nurodomos tik disciplinos ir joms skirtas valandų skaičius. Tikètina, kad detali programa su užsièmimų temomis nebuvo parengta ir labiausiai priklausè nuo dèstytojų. Pirmieji šiek tiek konkretesni mokymo planai parengti ruošiantis Vytauto Didžioji karininkų kursų aviacijos skyriaus II laidos (1928-1930 m.) studijoms ${ }^{88}$.

\footnotetext{
82 Pyragius, J. (red.) Mūsų sparnai. Lietuvos aviacijos istorija 1919-1929. Kaunas, 1929, p. 29-32.

83 Isakymas Karo aviacijos mokyklai Nr. 76, 1919 m. gegužès 26 d. LCVA, f. 1451, ap. 3, b. 1, 1. 28-29; İsakymas Karo aviacijos mokyklai Nr. 92, 1919 m. birželio 11 d. LCVA, f. 1451, ap. 3, b. 1, l. 34; Isakymas Karo aviacijos mokyklai Nr. 210, 1919 m. spalio 7 d. LCVA, f. 1451, ap. 3, b. 1, 1. 74 .

84 İsakymas Mokomajai oro eskadrilei Nr. 27, 1921 m. kovo 13 d. LCVA, f. 531, ap. 1, b. 262, 1. nenumeruoti.

85 Isakymas aviacijai Nr. 4, 1922 m. sausio 23 d. LCVA, f. 1323, ap. 1. b. 44, 1. 4.

86 Gustaitis, A. Lakūnų ir žvalgų mokymas mūsų aviacijoje. Kardas, Nr. 14, 1925, p. $10-12$.

87 Žigaras, F. Karininkų rengimo ir jų kvalifikacijos kèlimo sistema 1919-1940 m. II dalis. Vilnius, 2018, p. 38.

88 Ten pat, p. $49-51$.
} 
1921-1923 m. Mokomosios eskadrilès aviacijos kursuose pagrindinių teorinių disciplinų ${ }^{89}$ dèstytojai keitèsi minimaliai. Daugiausia kursuose dèstė ltn. Eugenijus Kraucevičius, vyr. ltn. Antanas Gustaitis, inž. Timinskas, inž. Adolfas Bliumentalis ir gen. ltn. J. Kraucevičius. Pastarieji du dèstytojai buvo igiję specialų aviacijos srities išsilavinimą ir sukaupę ilgametę patirtị. Nuo $1924 \mathrm{~m}$. vis didesnę pradiniame teoriniame rengime dalyvavusių dėstytojų dalị sudarè asmenys, turintys paviršutinišką aviacijos srities išsilavinimą ir daugiausia besiremiantys savo kelerių metų praktika.

Populiari pradinio teorinio rengimo mokomoji priemonè 19191928 m. buvo nedideliais tiražais dauginimo prietaisais atspausdinti paskaitų konspektai. Pirmieji Mokomosios eskadrilès aviacijos kursų klausytojams skirti konspektai buvo išleisti 1924 m. (žr. 1 lentelę). Pusę jų parengè 1923-1925 m. Mokomajai eskadrilei vadovavęs vyr. ltn. A. Gustaitis. $1924 \mathrm{~m}$. išleistuose konspektuose pateikiama ne visa disciplinos svarbiausia informacija, o tik konkrečių dèstytojų atrinka ir skaitytose paskaitose naudota medžiaga. Taip pat išanalizavus 1 lentelejje pateiktus 1924 m. išleistus paskaitų konspektus, galima manyti, kad jie kartu galejo būti ir pradinio teorinio rengimo programa.

1 lentelè. 1919-1928 m. išleistos pradinio teorinio rengimo mokomosios priemonès

\begin{tabular}{|c|c|c|c|c|}
\hline Pavadinimas & Autorius & $\begin{array}{c}\text { Išleidimo } \\
\text { metai }\end{array}$ & Leidèjas & $\begin{array}{c}\text { Tiražas, leidybos } \\
\text { büdas }\end{array}$ \\
\hline $\begin{array}{c}\text { Aviacijos istorijos } \\
\text { konspektas }\end{array}$ & $\begin{array}{c}\text { Vyr. Itn. Antanas } \\
\text { Gustaitis }\end{array}$ & $1924 \mathrm{~m}$. & $\begin{array}{c}\text { Aviacijos } \\
\text { kursai }\end{array}$ & $\begin{array}{c}\text { 25, atspausdinta } \\
\text { dauginimo } \\
\text { prietaisu }\end{array}$ \\
\hline $\begin{array}{c}\text { Bendros } \\
\text { meteorologijos ir } \\
\text { aeronavigacijos žinios }\end{array}$ & N. D. & $1924 \mathrm{~m}$. & $\begin{array}{c}\text { Aviacijos } \\
\text { kursai }\end{array}$ & $\begin{array}{c}25 \text {, atspausdinta } \\
\text { dauginimo } \\
\text { prietaisu }\end{array}$ \\
\hline $\begin{array}{c}\text { Aviacijos teorijos } \\
\text { konspektas }\end{array}$ & $\begin{array}{c}\text { Vyr. ltn. Antanas } \\
\text { Gustaitis }\end{array}$ & $1924 \mathrm{~m}$. & $\begin{array}{c}\text { Aviacijos } \\
\text { kursai }\end{array}$ & $\begin{array}{c}25 \text {, atspausdinta } \\
\text { dauginimo } \\
\text { prietaisu }\end{array}$ \\
\hline
\end{tabular}

${ }^{89}$ Pastaba. Omenyje turimos šios disciplinos: aviacijos teorija, aviacijos istorija, aviacijos taktika, aviaciniai varikliai, aviacinès technologijos. 
Lietuvos karo aviacijos 1919-1940 m. skraidančiojo personalo rengimo sistema

\begin{tabular}{|c|c|c|c|c|}
\hline $\begin{array}{l}\text { Medžiagų atsparumas } \\
\text { ir lëktuvo statika* }\end{array}$ & $\begin{array}{l}\text { Inž. Adolfas } \\
\text { Bliumentalis }\end{array}$ & $1924 \mathrm{~m}$ & $\begin{array}{c}\text { Aviacijos } \\
\text { kursai }\end{array}$ & $\begin{array}{c}\text { 25, atspausdinta } \\
\text { dauginimo } \\
\text { prietaisu }\end{array}$ \\
\hline $\begin{array}{l}\text { Aviacinių medžiagų } \\
\text { technologijos } \\
\text { konspektas }^{*}\end{array}$ & $\begin{array}{l}\text { Inž. Adolfas } \\
\text { Bliumentalis }\end{array}$ & $1924 \mathrm{~m}$ & $\begin{array}{c}\text { Aviacijos } \\
\text { kursai }\end{array}$ & $\begin{array}{c}\text { 25, atspausdinta } \\
\text { dauginimo } \\
\text { prietaisu }\end{array}$ \\
\hline
\end{tabular}

Lentelè sudaryta autoriaus pagal: Gustaitis, A. Aviacijos istorijos konspektas. Kaunas, 1924, p. 1-24; Bendros meteorologijos ir aeronavigacijos žinios. Kaunas, 1924, p. 1-14; Gustaitis, A. Aviacijos teorijos konspektas. Kaunas, 1924, p. 1-29. Lietuvos aviacijos muziejus (toliau - LAM), GEK 15528; Kariuomenés leidiniu 1918-1931 m. katalogas. Kaunas, 1932, p. 57-58.

* Konspektas išleistas rusų kalba.

Praktinis pradinis rengimas $1919 \mathrm{~m}$. vyko Karo aviacijos mokykloje, o nuo 1920 m. - Mokomojoje eskadrilèje. Pažymėtina, kad atliekant tyrimą nepavyko aptikti duomenų apie pradinio praktinio rengimo eigą ir turinị, tačiau išanalizavus atsiminimus ir Mokomosios eskadrilès ịsakymus galima nustatyti preliminarias bendrąsias tendencijas. Po teorinių kursų pabaigoje surengtų egzaminų buvo pradedamas pradinis praktinis rengimas $^{90}$. Kauno aerodrome instruktoriai skraidyti moke Vokietijos Albatros Flugzeugwerke GmbH gamykloje 1917 m. pagamintais mokomaisiais lèktuvais Albatros B. $I I^{91}$. Pirmajji savarankišką skrydị būsimi lakūnai atlikdavo po 60 mokomųjų skrydžių. Kariai, kuriuos reikèjo ilgiau mokyti, buvo laikomi nepakankamai gabiais ir jų mokymas buvo nutraukiamas arba jie rengiami kaip oro žvalgai ${ }^{92}$. Po pirmojo savarankiško skrydžio karys pradėdavo skraidyti tolesniam mokymui skirtais lèktuvais Albatros C. I, Albatros C. III ir Rumpler C. I. Po apie 30 val. mokomųjų skrydžių šiais lèktuvais karys atlikdavo pirmąji savarankišką skrydi koviniu lèktuvu (pavyzdžiui, LVG C. VI). Pirmasis skrydis koviniu lèktuvu buvo laikomas pradinio praktinio rengimo pabaiga, o karys iš Mokomosios eskadrilès buvo perkeliamas ị vieną kovinių eskadrilių. Pažymėtina, kad

90 Mikènas, J. Gyvenimo skrydis. Kaunas, 1994, p. 27.

91 Ramoška, G. Pirmieji Lietuvos karo aviacijos lèktuvai 1919-1923 m. Plieno sparnai, Nr. 1, 1992, p. 2-7.

92 Gustaitis, A. Lakūnų ir žvalgų mokymas mūsų aviacijoje. Kardas, Nr. 14, 1925, p. 10-12. 
pradinio praktinio rengimo metu karys nebuvo mokomas sudètingesnès skrydžio technikos (aukštojo pilotažo) - daugiau dėmesio buvo skiriama skrydžio technikai, nei jos taikymui vykdant kovines užduotis ${ }^{93}$. Pažymètina, kad būsimųjų oro žvalgų pradinio praktinio rengimo trukmès ir apimties atliekant tyrimą nepavyko nustatyti.

1919-1925 m. skraidyti moke išskirtinai Pirmojo pasaulinio karo lakūnai. 1919 m. skraidymo instruktoriais dirbo buvusio Vokietijos imperijos kariuomenès aviacijos dalinio Flieger Abteilung Nr. 425 lakūnai $^{94}$ (žr. 2 lentelę). Vèliau, iki 1922 m. rudens, pagrindinis instruktorius buvo vyr. ltn. Pranas Hiksa, trumpai jam padejo karo lakūnas vyr. ltn. Otto Rahnas. Rusijos imperijoje ir Jungtineje Karalysteje gerą aviacijos srities išsilavinimą ịgijęs P. Hiksa karo veiksmuose nebuvo dalyvavęs, taip pat neturejjo mokymo skraidyti patirties, o per trumpą tarnybos Lietuvos karo aviacijoje laikotarpi patyrè keliolika ịvairaus pobūdžio avarijų ${ }^{95} .1922 \mathrm{~m}$. ji pakeitè didelę patirtị turintis Pirmojo pasaulinio karo lakūnas Jurgis Pavlovas, prieš tarnybą Lietuvos karo aviacijoje pusantrų metu tarnavęs skraidymo instruktoriumi $^{96}$. 1922-1927 m. J. Pavlovas buvo pagrindinis Lietuvos karo aviacijos instruktorius ir per pirmajj Lietuvos karo aviacijos dešimtmetị savarankiškiems skrydžiams parengè daugiausiai lakūnų, palyginti su kitais skraidymo instruktoriais ${ }^{97}$. Po $1926 \mathrm{~m}$. gruodžio $16 \mathrm{~d}$. perversmo pasikeitus Lietuvos kariuomenès ir karo aviacijos vadovybei nuspręsta sutarties su rusų kilmès instruktoriumi J. Pavlovu nebepratęsti ${ }^{98}$. Nuo 1925 m. J. Pavlovui padèti ị Mokomąją eskadrilę buvo komandiruojami geresnius skraidymo igūdžius turintys lakūnai, jie vasaromis da-

\footnotetext{
93 Mikėnas, J. Gyvenimo skrydis. Kaunas, 1994, p. 25-31.

94 Ramoška, G. Lietuvos aviacija. Kaunas, 2009, p. 19.

95 Hiksa, P. Gyvenimas kaip skrydis. Vilnius, 2014, p. 91-94, 111-112.

96 Mokomosios oro eskadrilès laisvai samdomo karo lakūno Jurgio Pavlovo tarnybos lapas, 1927 m. rugpjūčio 9 d. $L C V A$, f. 631, ap. 7, b. 5556, 1. 2; Žinios apie karo lakūną Jurgi Pavlovą. LCVA, f. 930, ap. 8, b. 48, 1. 74.

97 Pyragius, J. (red.), Mūsų sparnai. Lietuvos aviacija 1919-1929. Kaunas, 1929, p. 67.

98 Vyriausiojo štabo administracinès valdybos viršininko $1927 \mathrm{~m}$. vasario $2 \mathrm{~d}$. raštas Nr. 15742 Aviacijos viršininkui. LCVA, f. 930, ap. 5, b. 3202, 1. 173; Aviacijos viršininko 1927 m. liepos 21 d. raportas Nr. 1080 Vyriausiojo štabo viršininkui. LCVA, f. 930, ap. 5, b. $3202,1.170$.
} 
lyvaudavo pradiniame skraidančiojo personalo mokyme ${ }^{99}$ (žr. 2 lentelę). Pirmojo pasaulinio karo lakūnų svariausias privalumas buvo vykstant realiems karo veiksmams sukaupta skraidymo patirtis, tačiau absoliuti jų dauguma neturẻjo specialių žinių, kaip mokyti skraidyti, ir išskirtinai rèmési tik savo asmenine patirtimi. Galima konstatuoti, kad né vienas skraidyti mokęs instruktorius, išskyrus J. Pavlovą, neturèjo patirties, kaip mokyti skraidyti.

2 lentelè. 1919-1928 m. pradiniame praktiniame rengime dalyvavę skraidymo instruktoriai

\begin{tabular}{|c|c|}
\hline Pradinio praktinio rengimo institucija & $\begin{array}{l}\text { Rengime dalyvavę } \\
\text { skraidymo instruktoriai }\end{array}$ \\
\hline Karo aviacijos mokyklos I laida, 1919 m. & $\begin{array}{l}\text { Vyr. ltn. Fricas Šulcas, } \\
\text { vyr. ltn. Haris Roteris, } \\
\text { vyr. ltn. Erichas Kuligowskis, } \\
\text { vyr. ltn. Pranas Hiksa }\end{array}$ \\
\hline 1920 m. Mokomojo būrio kursai & $\begin{array}{l}\text { Vyr. ltn. P. Hiksa, } \\
\text { vyr. ltn. Otto Rahn }\end{array}$ \\
\hline 1921 m. Mokomosios eskadrilès aviacijos kursai & Vyr. ltn. P. Hiksa \\
\hline 1922 m. Mokomosios eskadrilès aviacijos kursai & Jurgis Pavlovas \\
\hline 1922-1923 m. Mokomosios eskadrilès aviacijos kursai & J. Pavlovas \\
\hline 1924-1925 m. Mokomosios eskadrilès aviacijos kursai* & J. Pavlovas, vrš. Jonas Mikėnas \\
\hline $\begin{array}{l}\text { Vytauto Didžiojo karininkų kursų aviacijos skyrius, } \\
\text { I laida, } 1927 \text { m. }^{\star}\end{array}$ & Vrš. J. Mikènas \\
\hline $\begin{array}{c}\text { Vytauto Didžiojo karininkų kursų aviacijos skyrius, } \\
\text { II laida, } 1930 \mathrm{~m} .^{*}\end{array}$ & $\begin{array}{l}\text { Vyr. ltn. Jeronimas Garolis, } \\
\text { kpt. Česlovas Januškevičius }\end{array}$ \\
\hline
\end{tabular}

Lentelè sudaryta autoriaus pagal: [̦sakymai Mokomajai oro eskadrilei Nr. 4274, 1924 m. birželio 29 d.-rugsèjo 30 d. LCVA, f. 531, ap. 1, 270, l. 90-147; [ Isakymas aviacijai Nr. 27, $1922 \mathrm{~m}$. balandžio 22 d. LCVA, f. 1323, ap. 1, b. 44, 1. 28; Isakymas aviacijai Nr. 31, $1922 \mathrm{~m}$. liepos 21 d. LCVA, f. 1323, ap. 1, b. 44, 1. 33; Isakymas aviacijai Nr. 37, 1923 m. gegužès 17 d. LCVA, f. 1323, ap. 1, b. 66, 1. 5657; I sakymas Mokomajai oro eskadrilei Nr. 30, 1927 m. gegužès 10 d. LCVA, f. 531, ap. 1, b. 280, l. nenumeruoti; Isakymas aviacijai Nr. 87, 1929 m. spalio 11 d. LCVA, f. 1323, ap. 1, b. 185, 1. 112; Isakymas aviacijai Nr. 16, 1930 m. gegužès 16 d. LCVA, f. 1323, ap. 1, b. 201, 1. 25; İsakymas Mokomajai oro eskadrilei

99 Mikenas, J. Gyvenimo skrydis. Kaunas, 1994, p. 38-39; Pyragius, J. (red.), Mūsų sparnai. Lietuvos aviacija 1919-1929. Kaunas, 1929, p. 66-67. 
Nr. 30, 1928 m. liepos 19 d. LCVA, f. 531, ap. 1, b. 283, 1. 21; Mikènas, J. Gyvenimo skrydis. Kaunas, 1994, p. 25-27, 39-41; Dovydaitis, J. Nepriklausomybes kovu lakūnai. Kaunas, 2014, p. 104; Pyragius, J. (red.) Mūsu sparnai. Lietuvos aviacija 1919-1929. Kaunas, 1929, p. 65-68; Brazys, B. Gyvenimas ir tarnyba. Plieno sparnai, Nr. 2, 1994, p. 82-83.

${ }^{*}$ Pastaba. Atliekant tyrimą dèl duomenų stokos nepavyko nustatyti visų 1925-1928 m. Lietuvos karo aviacijos skraidymo instruktorių.

Teorinio ir praktinio rengimo detalių programų trūkumas leidžia manyti, kad 1919-1928 m. nebuvo apibrèžtas siektinas rengimo rezultatas, t. y. kvalifikacija, kurią turètų igyti karys, baigęs kiekvieną rengimo sistemos etapą. Galima teigti, kad aptariamuoju laikotarpiu skraidančiojo personalo rengimas ypač priklausè nuo teorinių mokomųjų dalykų dèstytojų ir skraidymo instruktorių. Pasikeitus jiems, keisdavosi ir rengimo turinys, todèl skirtingais metais rengimo sistemoje dalyvavę kariai ịgydavo skirtingų žinių ir gebejjimų.

Baigus pradin̨ rengimo etapą, tolesnis skraidančiojo personalo rengimas vyko kovinèse eskadrilèse ${ }^{100}$. I eskadriles perkeltiems kariams buvo pavedama eiti karo lakūno arba oro žvalgo pareigas. Rengimas eskadrilèse buvo orientuotas tik ị praktinių igūdžių tobulinimą, o teorinių žinių gilinimas paliktas kiekvieno kario asmeninei iniciatyvai. Praktinis rengimas kovinèse eskadrilèse buvo individualizuotas ir jo turinys nebuvo apibrèžtas jokioje mokymo programoje.

Visų lakūnų tolesnị rengimą vienijęs bruožas buvo aukštojo pilotažo kursai, kurių programą sudarè techniškai sudètingesnès 9 pilotažo figūros. Karo aviacijos viršininkui ịsakius, $1922 \mathrm{~m}$. Mokomojoje eskadrilèje buvo surengti pirmieji aukštojo pilotažo kursai, juose Pirmojo pasaulinio karo naikintuvu Foker D VII pilotažo mokẻ karo lakūnas instruktorius J. Pavlovas ${ }^{101}$. Po šių kursų tolesnis būsimų karo lakūnų aukštojo pilotažo mokymas buvo patikètas J. Pavlovo $1922 \mathrm{~m}$. apmokytiems lakūnams. 1923 m. gegužès $17 \mathrm{~d}$. buvo sudaryta trijų mokinių aukštojo pilotažo grupè, o jos instruktoriumi paskirtas prieš metus J. Pavlovo vadovaujamus aukštojo pilotažo kursus baigęs Mokomosios eskadrilès vadas

\footnotetext{
${ }^{100}$ Brazys, B. Gyvenimas ir tarnyba. Plieno sparnai, Nr. 2, 1994, p. 82-83.

${ }^{101}$ Issakymas aviacijai Nr. 22, 1922 m. gegužès 23 d. LCVA, f. 1323, ap. 1, b. 44, 1. 22; İsakymas aviacijai Nr. 31, 1922 m. liepos 21 d. LCVA, f. 1323, ap. 1, b. 44, 1. 33.
} 
vyr. ltn. A. Gustaitis ${ }^{102}$. Vèliau, iki pat ketvirtojo dešimtmečio pradžios, aukštojo pilotažo mokymas vyko individualiai, už ji buvo atsakinga 1-oji eskadrilè ir joje tarnavęs J. Pavlovo kursų absolventas E. Kraucevičius ${ }^{103}$.

Po dvejų trejų metų praktikos eskadrileje karo aviacijos viršininkas suteikdavo karo lakūno arba oro žvalgo vardą. Kvalifikacinio vardo suteikimas reiške baigtą rengimo kursą. Vis dèlto pažymètina, kad šio kvalifikacinio vardo suteikimo sąlygos nebuvo aiškiai apibrèžtos ir neretai priklausè nuo karo aviacijos viršininko gen. ltn. J. Kraucevičiaus nuomonés. Išanalizavus ịsakymus dèl karo lakūno arba oro žvalgo vardo suteikimo galima teigti, kad šie kvalifikaciniai vardai buvo suteikiami skirtingą patirtị ir nevienodą skaičių užduočių atlikusiems kariams ${ }^{104}$.

\subsection{Perèjimas prie trijų pakopų rengimo sistemos (1929-1931 m.)}

1928 m. skraidančiojo personalo rengime prasidèjo konceptualūs pokyčiai. Po 1926 m. gruodžio 17 d. karinio perversmo karo aviacijos viršininku paskirtas gen. št. plk. ltn. Stasys Pundzevičius sudarė komisiją, kuri turèjo pateikti karo lakūno ir oro žvalgo kvalifikacinių vardų suteikimo taisyklių projektą. Pavestą užduotį atlikusi karo lakūno kpt. Antano Mačiuikos vadovaujama komisija $1928 \mathrm{~m}$. birželio $26 \mathrm{~d}$. karo aviacijos viršininkui pristate parengtą taisyklių projektą ${ }^{105}$. Jame pirmą kartą buvo nustatyti konkretūs reikalavimai, kuriuos privalèjo įvykdyti karys, siekiantis gauti karo lakūno arba oro žvalgo vardą. Suderinus su Lietuvos kariuomenès Vyriausiojo štabo viršininku ${ }^{106}, 1929 \mathrm{~m}$. kovo $28 \mathrm{~d}$. karo

${ }^{102}$ Isakymas aviacijai Nr. 37, 1923 m. gegužès 17 d. LCVA, f. 1323, ap. 1, b. 66, 1. 56.

${ }^{103}$ Pyragius, J. (red.) Mùsu sparnai. Lietuvos aviacija 1919-1929. Kaunas, 1929, p. 54; Isakymas karo aviacijai Nr. 104, 1926 m. rugsejjo 3 d. LCVA, f. 1323, ap. 1, b. 132, 1. 110. ${ }^{104}$ Gamziukas, A. Garbingiausias karo lakūno apdovanojimas Lietuvos karo aviacijos garbès ženklas „Plieno sparnai“ 1932-2004 m., kn. Eugenijus Raubickas, Ženklas ant munduro. Vilnius: LR krašto apsaugos ministerija, 2005, 12-13; Isakymas aviacijai Nr. 23, 1923 m. kovo 27d. LCVA, f. 1323, ap. 1, b. 66, 1. 34; Isakymas aviacijai Nr. 62, 1923 m. rugpjūčio 4 d. LCVA, f. 1323, ap. 1, b. 66, 1. 94-5; Pyragius, J. (red.) Mūsų sparnai. Lietuvos aviacijos istorija 1919-1929. Kaunas, 1929, p. 50, 54.

${ }^{105}$ Kpt. Antano Mačiuikos raportas Aviacijos viršininkui Nr. 64, 1928 m. birželio 26 d. LCVA, f. 1323, ap. 1, b. 177, 1. 1.

106 Aviacijos viršininko raportas Vyriausiojo štabo viršininkui Nr. 57/sl, 1929 m. sausio 22 d. LCVA, f. 1323, ap. 1, b. 177, 1. 38. 
aviacijos viršininkas patvirtino taisykles karo lakūno ir oro žvalgo vardui gauti ${ }^{107}$. Šių taisyklių patvirtinimas paskatino parengti dar vienas, jau tiesiogiai su skraidančiojo personalo rengimu susijusias, taisykles. $1929 \mathrm{~m}$. vasaros pradžioje, remdamasi kpt. A. Mačiuikos komisijos įdirbiu ${ }^{108}$, naujai sukurta mjr. A. Gustaičio vadovaujama komisija parengè taisyklių projektą, kuriame apibrèžè privalomas kasmetines skraidymo pratybas karo lakūnams ir oro žvalgams ${ }^{109}$. Be esminių pakeitimų $1929 \mathrm{~m}$. liepos $31 \mathrm{~d}$. šis taisyklių projektas buvo patvirtintas ir pavesta juo vadovautis organizuojant kovinių eskadrilių skraidymo pratybas $^{110}$.

Paradoksalu, tačiau pradinis siekis standartizuoti ir padaryti skaidresnị kvalifikacinių vardų suteikimo procesą paskatino sukurti naują skraidančiojo personalo rengimo sistemą. $1929 \mathrm{~m}$. vasaros viduryje de facto buvo įtvirtinta nauja trijų pakopų skraidančiojo personalo rengimo sistema. Daugiau ị aviaciją, veikiančią taikos sąlygomis, orientuotoje rengimo sistemoje pirmoji pakopa buvo skirta bazinių teorinių žinių ir praktinių igūdžių igijimui, antroji - specialiųjų praktinių igūdžių formavimui, trečioji - kario iggytų igūdžių ir žinių palaikymui.

Kaip ir anksčiau, skraidančiojo personalo rengimo pirmąją pakopą sudare pradinis teorinis ir praktinis rengimas. Vis dèlto, skirtingai nei anksčiau, nuo 1929 m. buvo aiškiai apibrěžtas pirmosios rengimo pakopos tikslas - šią pakopą baigę kariai privalejjo turèti teorinių žinių ir praktinių igūdžių, kurie būtų pakankami karo lakūno arba oro žvalgo pareigoms kovinèse eskadrilèse atlikti.

1929-1931 m. pradinis teorinis rengimas vyko specialiuose Mokomosios eskadrilés aviacijos kursuose, skirtuose puskarininkiams ${ }^{111}$, ir Vytauto Didžiojo karininkų kursų aviacijos skyriuje (žr. 9 lentelę). Pra-

${ }^{107}$ Slaptas iqsakymas aviacijai Nr. 1/sl, 1929 m. kovo 28 d. LCVA, f. 1323, ap. 1, b. 186, 1. $1,4-15$.

${ }^{108}$ Kpt. A. Mačiuikos raportas Aviacijos viršininkui Nr. 33/sl, 1929 m. gegužès 28 d. LCVA, f. 1323, ap. 1, b. 177, 1. 56-60.

${ }^{109}$ Mjr. A. Gustaičio komisijos aktas, 1929 m. birželio 26 d. LCVA, f. 1323, ap. 1, b. 177, 1. $53-55$.

${ }^{110}$ Slaptas iqsakymas aviacijai Nr. 5/sl, 1929 m. liepos 31 d. LCVA, f. 1323, ap. 1, b. 186, 1. 18 .

${ }_{111}$ Pastaba. Nepublikuotuose dokumentuose šie kursai kartais vadinami Puskarininkių lakūnų mokykla. Vis dèlto ji neturejo patvirtinto statuto, vadovo, atskiros mokymo programos ir veike trumpiau nei vienus metus. 
dinio teorinio rengimo disciplinos ir jas dėsčiusių instruktorių sudètis reikšmingai nesiskyrė nuo 1921-1928 m. Papildomai puskarininkiams aviacijos kursuose déstyta keletas bazinių karo mokslo ir bendrojo lavinimo mokomųjų dalykų ${ }^{112}$. Atliekant tyrimą pradinio teorinio rengimo detalios programos nepavyko rasti, todèl, tikètina, kad buvo remiamasi anksčiau parengtais konspektais ir teorinio rengimo programos turinys priklausė nuo dėstytojo sprendimo. Šiek tiek smulkesnis mokymo planas buvo parengtas ruošiantis Vytauto Didžioji karininkų kursų aviacijos skyriaus III laidos (1930-1932 m.) studijoms ${ }^{113}$. Nors, palyginti su 19211926 m., šis planas buvo gerokai konkretesnis, tačiau vis tiek nebuvo visavertè teorinio rengimo programa.

Teorines disciplinas dèsčiusių lektorių sudètis 1929-1931 m. buvo atnaujinta ittraukiant vis daugiau karo aviacijos karininkų, kurie tarnybą pradèjo 1922-1925 m. Daugumos naujų pradejjusių dèstyti lektorių išsilavinimas buvo tik trumpalaikiai Mokomosios eskadrilès aviacijos kursai. Pažymètina, kad 1929-1931 m. buvo parengti už paskaitų konspektus pranašesni pirmieji specialūs aviacijos disciplinų vadovèliai (žr. 3 lentelę).

3 lentelè.1929-1931 m. išleistos pradinio teorinio rengimo mokomosios priemonès

\begin{tabular}{|c|c|c|c|c|}
\hline Pavadinimas & Autorius & $\begin{array}{l}\text { Išleidimo } \\
\text { metai }\end{array}$ & Leidèjas & $\begin{array}{l}\text { Tiražas, } \\
\text { leidybos } \\
\text { būdas }\end{array}$ \\
\hline $\begin{array}{c}\text { Taisyklès motorų } \\
\text { Fiat } A-20 \text { ir } A-22 \\
\text { vartojimui }\end{array}$ & $\begin{array}{l}\text { Ltn. Jonas Mikènas } \\
\text { (vertèjas) }\end{array}$ & $1929 \mathrm{~m}$. & $\begin{array}{l}\text { Kariuomenès vyr. } \\
\text { štabo Spaudos ir } \\
\text { švietimo skyrius }\end{array}$ & $\begin{array}{c}1000, \\
\text { "Spindulio“ } \\
\text { spaustuvė }\end{array}$ \\
\hline $\begin{array}{l}\text { Aerodromų } \\
\text { parinkimas }\end{array}$ & Kpt. Vladas Morkus & $1929 \mathrm{~m}$. & $\begin{array}{l}\text { Kariuomenès vyr. } \\
\text { štabo Spaudos ir } \\
\text { švietimo skyrius }\end{array}$ & $\begin{array}{c}4500, \\
\text { M. Kuktos } \\
\text { spaustuvė }\end{array}$ \\
\hline $\begin{array}{c}\text { Aviacijos } \\
\text { medžiagos } \\
\text { technologija } \\
\text { (konspektas) }\end{array}$ & $\begin{array}{l}\text { Inž. Adolfas } \\
\text { Bliumentalis }\end{array}$ & $1930 \mathrm{~m}$. & $\begin{array}{l}\text { Kariuomenès vyr. } \\
\text { štabo Spaudos ir } \\
\text { švietimo skyrius }\end{array}$ & $\begin{array}{c}40, \\
\text { atspausdinta } \\
\text { dauginimo } \\
\text { prietaisu }\end{array}$ \\
\hline
\end{tabular}

${ }^{112}$ Puskarininkių lakūnų mokyklos mokinių pažymiai, 1929 m. LCVA, f. 1451, ap. 3, b. 4, 1. 1.

113 Žigaras, F. Karininkų rengimo ir ju kvalifikacijos kèlimo sistema 1919-1940 m. II dalis. Vilnius, 2018, p. 49-51. 


\begin{tabular}{|c|c|c|c|c|}
\hline $\begin{array}{c}\text { Aeronautine } \\
\text { meteorologija }\end{array}$ & $\begin{array}{c}\text { Kpt. Bronius } \\
\text { Vaivada }\end{array}$ & $1931 \mathrm{~m}$. & $\begin{array}{c}\text { Kariuomenės vyr. } \\
\text { štabo Spaudos ir } \\
\text { švietimo skyrius }\end{array}$ & $\begin{array}{c}2000, \\
\text { "Spindulio“ } \\
\text { spaustuvė }\end{array}$ \\
\hline Oro žvalgyba & $\begin{array}{c}\text { Mjr. Harold } \\
\text { Porter (verte kpt. } \\
\text { Vytautas Antanas } \\
\text { Plaušinaitis) }\end{array}$ & $1931 \mathrm{~m}$. & $\begin{array}{c}\text { Kariuomenès vyr. } \\
\text { štabo Spaudos ir } \\
\text { švietimo skyrius }\end{array}$ & $\begin{array}{c}1000, \\
\text { "Spindulio“ } \\
\text { spaustuve }\end{array}$ \\
\hline
\end{tabular}

Lentele sudaryta autoriaus pagal: Kariuomenés leidinių 1918-1931 m. katalogas. Kaunas, 1932, p. 57-58; Taisykles motory Fiat A-20 ir A-22 vartojimui (vertejjas Jonas Mikènas). Kaunas, 1929, p. 1-79; Morkus, V. Aerodromu parinkimas. Kaunas, 1929, p. 1-17; Vaivada, B. Aeronautine meteorologija. Kaunas, 1931, p. 1-250; Porter, H., E. Oro žvalgyba. Kaunas, 1931, p. 1-113.

Pradinis praktinis rengimas buvo organizuojamas Mokomojoje eskadrilejje ir truko 4-5 mènesius. Kariai skraidyti buvo mokomi jau minètais vokiečių konstrukcijos mokomaisiais lèktuvais Albatros B. II. Taip pat pirmą kartą mokomiesiems skrydžiams atlikti pradètas naudoti inž. A. Gustaičio konstrukcijos mokomasis lèktuvas ANBO II ${ }^{114}$. Pirmąji savarankišką skrydị būsimi lakūnai vidutiniškai atlikdavo po 80 mokomųjų skrydžių. Pažymėtina, kad kariai greičiau pirmąji savarankišką skrydi atlikdavo mokomuoju lèktuvu Albatros B. II (vidutiniškai po 69 skrydžių) nei naujuoju ANBO II (vidutiniškai po 110 skrydžių). Tolesniam praktiniam rengimui naudotas Albatros C. III lèktuvas, kuriuo pirmam savarankiškam skrydžiui kursų klausytojas pakildavo po vidutiniškai 50 mokomųjų skrydžių. Galiausiai atlikus pirmąji skrydi lèktuvu LVG C., VI pirmoji praktinio rengimo pakopa buvo laikoma baigta ir karys perkeliamas ị kovinę eskadrilę. Vidutiniškai iki perkèlimo ị kovinę eskadrilę būsimasis lakūnas atlikdavo apie 289 skrydžius (varijuoja nuo 343 iki 235 skrydžių) ir išskraidydavo apie 59 val. (varijuoja nuo 81 iki 46 val.) ${ }^{115}$.

1927 m. J. Pavlovui pasitraukus iš karo aviacijos, skraidančiojo personalo pradinis praktinis rengimas buvo galutinai patikètas anksčiau Mokomojoje eskadrileje parengtiems lakūnams ${ }^{116}$ (žr. 4 lentelę). Šie karo

\footnotetext{
${ }^{114}$ Ramoška, G. ANBO II. Pirmasis lietuviškas mokomasis lèktuvas. Plieno sparnai, Nr. 5, p. 1998, p. 12.

115 Aviacijos liktinių puskarininkių tarnybos I knyga. LCVA, f. 930, ap. 7, b. 3945, 1. 1-2, 64-65, 89-90. 101-102, 108-109, 114-115, 185-186.

116 Pyragius, J. (red.) Mūsų sparnai. Lietuvos aviacija 1919-1929. Kaunas, 1929, p. 65-67.
} 
lakūnai buvo paskirti skraidymo instruktoriais atsižvelgiant $\mathfrak{i}$ jų skraidymo igūdžius. Išskyrus kpt. E. Kraucevičių, nė vienas neturèjo kovinès patirties, o jų skraidymo stažas, iki paskiriant instruktoriais, buvo ganétinai mažas.

4 lentelè. 1929-1931 m. pradiniame praktiniame rengime dalyvavę skraidymo instruktoriai

\begin{tabular}{|c|c|}
\hline Pradinio praktinio rengimo institucija & $\begin{array}{c}\text { Rengime dalyvavę } \\
\text { skraidymo instruktoriai }\end{array}$ \\
\hline $\begin{array}{c}\text { Mokomosios eskadrilès aviacijos kursai } \\
\text { puskarininkiams, } 1929 \mathrm{~m} .\end{array}$ & Kpt. V. Švitris \\
\hline $\begin{array}{c}\text { Vytauto Didžiojo karininkų kursų aviacijos } \\
\text { skyrius, III laida, } 1932 \mathrm{~m} .\end{array}$ & $\begin{array}{c}\text { Kpt. V. Švitris, kpt. Č. Januškevičius, } \\
\text { kpt. Eugenijus Kraucevičius }\end{array}$ \\
\hline
\end{tabular}

Lentelè sudaryta autoriaus pagal: İsakymas aviacijai Nr. 87, 1929 m. spalio 11 d. LCVA, f. 1323, ap. 1, b. 185, 1. 112; Itsakymas aviacijai Nr. 16, 1930 m. gegužès 16 d. LCVA, f. 1323, ap. 1, b. 201, 1. 25; Pyragius, J. (red.), Mūsu sparnai. Lietuvos aviacija 1919-1929. Kaunas, 1929, p. 65-68; Kulnytė, B. (et. al.) Lietuvos kariuomenes karininkai 1918-1953, t. VII, Vilnius, 2007, p. 363.

$1929 \mathrm{~m}$. įtvirtintos skraidančiojo personalo rengimo sistemos antroji pakopa tapo pagrindine. Skraidančiajam personalui priskirtas karys, baigdamas antrąją pakopą, privalëjo būti pasiruošęs sudetingomis sąlygomis (vykstant karo veiksmams ar esant blogoms meteorologinèms sąlygoms) įvykdyti visas jam skirtas užduotis. Kaip ir anksčiau, šios pakopos rengimas buvo organizuojamas kovinèse eskadrilèse, tačiau nuo $1929 \mathrm{~m}$. jis tapo standartizuotas ir vykdomas pagal karo aviacijos viršininko patvirtintą 50 skirtingo pobūdžio užduočių programą. Antroji rengimo pakopa trukdavo $2-2,5 \mathrm{~m}$. ir išskirtinai buvo orientuota ị specialių teorinių ir praktinių žinių bei igūdžių igijimą. Visas kovinis rengimas vykdytas atsižvelgiant $\mathfrak{i}$ kario specializaciją (lakūnas ar oro žvalgas) bei eskadrilès pobūdị (naikintuvų ar žvalgybos). Vis dèlto nepriklausomai nuo eskadrilès pobūdžio visiems lakūnams (išskyrus oro žvalgus) buvo privalomas aukštojo pilotažo kursas. $1930 \mathrm{~m}$. aukštojo pilotažo mokymas buvo peržiūrètas ir pirmą kartą standartizuotas. Numatyta, kad visi lakūnai, išskyrus naikintuvų eskadrilių lakūnus, bus komandiruojami aukšto- 
jo pilotažo mokytis ị Mokomąją eskadrilę. Lyginant su 1922 m. pirmųjų aukštojo pilotažo kursų programa, $1930 \mathrm{~m}$. patvirtinta aukštojo pilotažo mokymo programa buvo reikšmingai papildyta naujais pratimais ${ }^{117}$. Pirmoji 6 lakūnų grupè pagal naująą programą dviejų mėnesių trukmès aukštojo pilotažo kursus baigè $1930 \mathrm{~m}$. spalio $3 \mathrm{~d} .{ }^{118}$

Taip pat $\mathfrak{i}$ antrąją rengimo pakopą nuo $1929 \mathrm{~m}$. buvo integruotas ir teorinis rengimas, kurio metu karys karo aviacijos viršininko patvirtinta tema turejo parengti ir apginti referatą, išlaikyti karo aviacijos viršininko sudarytos komisijos egzaminus. Ivykdęs visus šiuos reikalavimus karys buvo laikomas baigusiu antrają rengimo pakopą, ir jam karo aviacijos viršininkas suteikdavo karo lakūno arba oro žvalgo kvalifikacinị vardą ${ }^{119}$.

Iki 1929 m. buvo laikomasi prielaidos, kad skraidančiojo personalo rengimo kursas baigtas asmeniui suteikus karo lakūno arba oro žvalgo vardą. Šios prielaidos atsisakyta 1929 m. viduryje pavirtinus kasmetes kiekvienam lakūnui privalomas skraidymo programas. Pastarosios sudarytos atsižvelgiant $\mathfrak{i}$ tarnybos vietą ir specializaciją, taip pat orientuotos $\mathfrak{i}$ praktinių igūdžių palaikymą ir tobulinimą. Programas sudarè minimalus kiekis užduočių ir skrydžio valandų, kurios leistų neprarasti pirmosiose dviejose rengimo pakopose igytų igūdžių. Skraidymo programos kasmet buvo keičiamos, o jų apimtis vis didejo. Pavyzdžiui, 1929 m. naikintuvų eskadrileje tarnaujantis karo lakūnas privalejo atlikti 48 užduotis, kurioms igyvendinti skirta apie 30 val. skrydžių ${ }^{120} .1931 \mathrm{~m}$. naikintuvo pilotas per metus turejjo atlikti ne mažiau kaip 68 užduotis, kurių igyvendinimui buvo skirta 43 val., ir dar 20 val. praleisti ore dalyvaudamas kariuomenès manevruose $\mathrm{e}^{121}$.

Galima teigti, kad nuo 1929 m. rengimo sistema turèjo aiškiai apibrèžtą galutinị rengimo sistemos rezultatą - pasiekęs trečiąją rengimo pakopą, kiekvienas lakūnas ar oro žvalgas privalèjo mokèti atlikti nustatytus veiksmus ore ir ívykdyti pavestas užduotis, susijusias su jo specia-

\footnotetext{
${ }^{117}$ Issakymas aviacijai Nr. 16, 1930 m. gegužès 16 d. LCVA, f. 1323, ap. 1, b. 201, 1. 24-25.

118 Isakymas aviacijai Nr. 45, 1930 m. spalio 3 d. LCVA, f. 1323, ap. 1, b. 201, 1. 55.

119 Slaptas issakymas aviacijai Nr. 5/sl, 1929 m. liepos 31 d. LCVA, f. 1323, ap. 1, b. 186, 1. 18 .

${ }^{120}$ Slaptas įsakymas aviacijai Nr. 5/sl, 1929 m. liepos 31 d. LCVA, f. 1323, ap. 1, b. 186, 1. 18.

${ }^{121}$ Isakymas aviacijai Nr. 1/sl, 1931 m. kovo 26 d. LCVA, f. 1323, ap. 1, b. 225, 1. 1-6.
} 
lybe. Visa rengimo sistema nuo $1929 \mathrm{~m}$. buvo orientuota ị ši galutinị tikslą. 1929 m. patvirtinti dokumentai tapo atskaitos tašku toliau keičiant ir tobulinant skraidančiojo personalo rengimo sistemą.

\subsection{Trijų pakopų rengimo sistemos konsolidacija (1932-1940 m.)}

1929 m. ịvesta trijų pakopų rengimo sistema paveldèjo trūkumą, susijusị su pernelyg trumpa pirmaja rengimo pakopa. 1919-1932 m. tarnybos metu žuvo 21 Lietuvos karo aviacijoje tarnavęs karys, iš jų 20 - treniruodamiesi. Du trečdaliai žuvusiųjų turèjo palyginti mažai patirties - neseniai buvo baigę pirmają rengimo pakopą ir vykdè užduotis karo lakūno arba oro žvalgo vardui gauti. Pavyzdžiui, $1929 \mathrm{~m}$. Mokomosios eskadrilès aviacijos kursų 3 iš 12 absolventų žuvo pirmaisiais metais po jų baigimo. Bent minimaliai siekiant kompensuoti pirmosios rengimo pakopos spragas, daugiau demesio rengimui buvo skiriama antrojoje pakopoje. Didelis mirtingumas ir sparčiai plečiama antrosios rengimo pakopos programa signalizavo apie nesubalansuotą rengimo sistemą - kariui pirmojoje rengimo pakopoje buvo suteikiama nepakankamai ṫūdžių.

1931 m. pabaigoje Lietuvos karo aviacijos vadovybė inicijavo pokyčius bandydama spręsti keletą su skraidančiojo personalo rengimo sistema susijusių problemų ${ }^{122}$. Siekiant tobulinti skraidančiojo personalo rengimo sistemą ir suformuoti lakūnų ir oro žvalgų rezervą, buvo numatyta ịsteigti specialią mokyklą ${ }^{123}$. Karo aviacijos vadovybe $1931 \mathrm{~m}$. pabaigoje Vyriausiajam kariuomenès štabui pristatė parengtą specializuotos aviacijos mokyklos statuto (įstatymo) projektą ${ }^{124}$. Skubos tvarka patvirtinus statutą $^{125}, 1932$ m. gegužes 1 d. savo veiklą pradèjo Karo aviacijos mo-

${ }^{122}$ Generalinio štabo valdybos I-ojo skyriaus 1931 m. gruodžio 9 d. raštas Aviacijos viršininkui Nr. 3973/sl. LCVA, f. 1323, ap. 1, b. 241, 1. 96.

${ }^{123}$ Lietuvos Respublikos krašto apsaugos ministro $1932 \mathrm{~m}$. vasario 29 d. skubus raštas Ministrui Pirmininkui Nr. 1527. LCVA, f. 1323, ap. 1, b. 241, 1. 92.

${ }^{124}$ Aviacijos puskarininkių lakūnų mokyklos isstatymo ir/ar statuto projektai. LCVA, f. 1323, ap. 1, b. 241, 1. 86-91, 93-95, 97-103.

${ }^{125}$ Aviacijos puskarininkių lakūnų mokyklos statutas. Vyriausybès žinios, 1932, balandžio 9, Nr. 381, p. 4. 
kykla, iš pradžių pavadinta Aviacijos puskarininkių lakūnų mokykla ${ }^{126}$. Taip pat karo aviacijos viršininko žinion grąžinti aviacijos kursai, kurie nuo 1926 m. buvo pavaldūs Vytauto Didžiojo karininkų kursų viršininkui ${ }^{127}$. Galima teigti, kad $1929 \mathrm{~m}$. perejus prie trijų pakopų rengimo programos pradiniam teoriniam ir praktiniam skraidančiojo personalo rengimui buvo skiriama mažiau dèmesio ir antroji rengimo pakopa buvo tapusi pati svarbiausia. Nuo $1932 \mathrm{~m}$. šis skraidančiojo personalo rengimo sistemos netolygumas buvo pradètas mažinti ypač išplètus pirmąją (apimančią pradinị teorinị ir praktinị rengimą) pakopą.

1933 m. karo aviacijos viršininkas patvirtino naujas kvalifikacinių vardų suteikimo taisykles, kuriose buvo apibrěžti minimalūs reikalavimai kiekvienam kvalifikaciniam vardui gauti. Taisyklèse numatyta, kad skraidantijj personalą sudaro trys grupès: skraidyti besimokantys lakūnai ar oro žvalgai, II rango karo lakūnai ir I rango karo lakūnai ${ }^{128}$. Patvirtinus kvalifikacinių vardų suteikimo taisykles buvo peržiūrèta skraidančiojo personalo rengimo sistema ir $1934 \mathrm{~m}$. sausio $25 \mathrm{~d}$. Vyriausiojo štabo viršininkas gen. ltn. Petras Kubiliūnas patvirtino atnaujintą Karo aviacijos skraidančiojo personalo rengimo planą ${ }^{129}$. Svarbiausia šio pokyčio ašis buvo viso skraidančiojo personalo rengimo sistemos susiejimas su kvalifikacinių vardų suteikimu. Pagal 1934 m. patvirtintą planą iki 1940 m. buvo organizuojamas viso Karo aviacijos skraidančiojo personalo rengimas.

Pirmąją rengimo pakopą sudare pradinis teorinis ir praktinis rengimas. Jis vyko Karo aviacijos mokykloje, Mokomojoje grupeje ir kovinèse eskadrilèse. 1932-1940 m. Karo aviacijos mokyklą baigè 5 lakūnų puskarininkių laidos, viena puskarininkių oro šaulių kursų laida ir dvi karininkų lakūnų ir oro žvalgų laidos (žr. 9 lentelę).

1932 m. pirmą kartą parengtas ir patvirtintas išsamus pradinio teori-

\footnotetext{
${ }^{126}$ Pastaba. 1932 m. gegužès 1 d. įsteigta mokykla buvo pavadinta Aviacijos puskarininkių lakūnų mokykla, 1933 m. rugsèjo mèn. patvirtintame naujame statute - Aviacijos puskarininkių lakūnų ir mechanikų mokykla, o nuo 1936 m. - Karo aviacijos mokykla. Pažymėtina, kad nuo pat mokyklos įstiegimo įvairiuose susirašinejjimo ir kituose dokumentuose mokykla vadinta Karo aviacijos mokykla. Atsižvelgiant $\underset{i}{t}$ tai, straipsnyje, išskyrus nuorodas i šaltinius, vartojamas pastarasis pavadinimas.

${ }^{127}$ Isakymas kariuomenei Nr. 64, $1931 \mathrm{~m}$. lapkričio $18 \mathrm{~d}$.

${ }^{128}$ Karo aviacijos lekiojančio personalo ị rangus pakèlimo taisyklès. LCVA, f. 1323, ap. 1, b. $261,1.92-93$.

${ }^{129}$ Karo aviacijos lekiojančio personalo mokymas. LCVA, f. 1451, ap. 3, b. 36, 1. 21-49.
} 
nio ir praktinio rengimo planas ir programa, kurioje pateikiama ne vien déstymo apimtis valandomis, bet ir konkretus programos turinys ${ }^{130}$. Pradinis puskarininkių lakūnų rengimas buvo suskirstytas ị penkis 6 mèn. trukmès etapus, iš kurių pirmasis apèmė bazinị kareivio kursą, aviacijos disciplinų dėstymą ir pradinị mokymą skraidyti. Antrajame etape dèmesys buvo sutelktas ị teorinị disciplinų dèstymą ir praktinių igūdžių formavimą dirbtuvèse, trečiajame - ì praktinių skraidymo igūdžių ugdymą bei baigiamas pradinis kareivio kursas. Ketvirtajame etape buvo baigiamas teorinis rengimas, o paskutiniajame - būsimi lakūnai stažuodavosi kovinèse eskadrilèse ir tobulindavo savo praktinius skraidymo igūdžius ${ }^{131}$.

1934-1940 m. pradinio teorinio rengimo programa buvo keturis kartus pakeista. Remiantis mokymosi iš patirties principu buvo keičiamas ir kai kurių disciplinų dėstymui skirtų valandų skaičius. Ypač, didinant užsiẻmimų skaičių, daugiau laiko skirta teorinių disciplinų pratyboms. Pavyzdžiui, Karo aviacijos mokyklos puskarininkių klasės lakūnų skyriaus I laidos kariai teorinių žinių ịtvirtinimui pritaikytose klasėse, dirbtuvèse ir lauko pratybose praleido 422 val., II laidos - 580 val., III laidos - 899 val. Atitinkamai daugiau laiko jie mokydavosi ir teorijos: I laida - 640 val., II laida - 800 val., o III laida - 745 val. Daugiau valandų buvo skiriama aviacijos variklių, avigacijos, aerologijos, medžiagų atsparumo ir technologijos kursams ${ }^{132}$. Taip pat dèl nepakankamų stojančiųjų matematikos ir fizikos žinių ${ }^{133}$ nuo $1934 \mathrm{~m}$. ketvirtadaliu buvo pailgintas šioms bendrosioms disciplinoms studijuoti skirtas laikas ${ }^{134}$.

1934 m. pirmą kartą parengta būsimiesiems karo lakūnams karinin-

${ }^{130}$ Puskarininkių lakūnų mokyklos mokymo planas. LCVA, f. 1451, ap. 3, b. 6, 1. 1-4; Dėstomųjų disciplinų mokomosios programos. LCVA, f. 1451, ap. 3, b. 6, 1. 11-46.

${ }^{131}$ Puskarininkių lakūnų mokyklos mokymo planas ir priedai. LCVA, f. 1451, ap. 3, b. 6, 1. $1,4,6-7$.

${ }_{132}$ Puskarininkių lakūnų mokyklos mokymo planas ir priedai. LCVA, f. 1451, ap. 3, b. 6, 1. 1, 4; Karo aviacijos mokyklos puskarininkių lakūnų klasès 1934-1936 m. dėstomųjų dalykų suskirstymas kategorijomis. LCVA, f. 1451, ap. 3, b. 15, 1. 7; Karo aviacijos mokyklos puskarininkių lakūnų klasės 1935-1937 m. dèstomųjų dalykų suskirstymas kategorijomis. LCVA, f. 1451, ap. 3, b. 22, 1. 3.

${ }^{133}$ Karo aviacijos mokyklos viršininko 1933 m. sausio 10 d. raštas Nr. 27 Aviacijos viršininkui. $L C V A$, f. 1451, ap. 3, b. 6, 1. 3 .

${ }^{134}$ Karo aviacijos mokyklos puskarininkių lakūnų klasès 1934-1936 m. dėstomųjų dalyku suskirstymas kategorijomis. LCVA, f. 1451, ap. 3, b. 15, 1. 7. 
kams skirta pradinio teorinio ir praktinio parengimo programa. Karininkų kursų teorinio rengimo programa, palyginti su puskarininkių, buvo labiau koncentruota ir orientuota išskirtinai ị aviacijos disciplinas, o iš bendrųjų dalykų dèstytos tik užsienio kalbos. 1936-1937 m. organizuojant antruosius kursus programa nebuvo pakeista ${ }^{135} .1935$ m. Karo aviacijos mokyklos rengimo programa integruota i Karo mokyklos programą ir būsimieji karininkai lakūnai ir oro žvalgai buvo rengiami jungtinèje programoje $^{136}$ (žr. 9 lentelę). Karo mokyklos aviacijos skyriaus kariūnai teoriškai ir praktiškai rengtis buvo komandiruojami ị Karo aviacijos mokyklą. I kurse kariūnai Karo aviacijoje mokykloje išklausydavo 60 val. teorinį kursą, o II-III kurse buvo tęsiamas jų teorinis rengimas ir vykdomas pradinis praktinis rengimas. Programos turinys ir jo apimtis reikšmingai nesiskyrè nuo lakūnų puskarininkių ir karininkų kursų programų ${ }^{137}$.

Pradinio teorinio rengimo disciplinas XX a. ketvirtojo dešimtmečio pradžioje dažniau dèstė patyrę karo aviacijos karininkai ir civiliai tarnautojai, specialųji išsilavinimą igiję užsienio aukštosiose mokyklose. Pavyzdžiai, kpt. Vytautas Jablonskis, inž. mjr. Antanas Gavelis, mjr. Viktoras Reimontas ${ }^{138}$. Ketvirtojo dešimtmečio pabaigoje dažniau lektoriais buvo skiriami Karo aviacijos mokykloje tarnavę karininkai, kurie, palyginti su ankstesniais dèstytojais, buvo igiję mažiau patirties ir neturejo specialaus išsilavinimo ${ }^{139}$.

Nuo 1934 m. intensyvejjant mokomųjų priemonių leidybai, buvo išleisti pirmieji svarbesnių teorinių disciplinų vadovèliai, kurių autoriai buvo konkrečioje srityje daugiau patirties ir žinių sukaupę lakūnai (žr. 5 lentelę).

\footnotetext{
${ }^{135}$ Karo aviacijos mokyklos karininkų kursų 1936-1937 m. mokymo planas. LCVA, f. 1451, ap. 3, b. 21, 1. 21.

${ }^{136}$ Abraitis, J. PLP Karo mokyklos XIX laidos 5-tis. Karys, 1988, balandis, Nr. 4 (1641), p. $150,153-156$.

${ }^{137}$ Pirmojo Lietuvos Prezidento Antano Smetonos karo mokyklos aviacijos skyriaus II laidos kariūnams aviacijos dalykų mokymo planas. $L C V A$, f. 1451, ap. 2, b. 36, 1. 1 .

${ }^{138}$ Karo aviacijos mokyklos puskarininkių lakūnų klasès lektorių sąrašas. LCVA, f. 1451, ap. 3, b. $15,1.9-10$.

${ }^{139}$ Karo aviacijos mokyklos puskarininkių klasės lakūnų skyriaus IV laidos /19371939 m./ lektorių sąrašas. LCVA, f. 1451, ap. 3, b. 29, 1. 6; Karo aviacijos mokyklos puskarininkių klasès lakūnų skyriaus V laidos lektorių sąrašas. LCVA, f. 1451, ap. 3, b. 38, 1. 3; Pirmojo Lietuvos Prezidento Antano Smetonos karo mokyklos aviacijos skyriaus II laidos kariūnams lektorių sąrašas. $L C V A$, f. 1451, ap. 2, b. 36, 1. 2.
} 
Pavyzdžiui, 1934 m. buvo išleistas karo lakūno ltn. Jono Mikèno parengtas vadovėlis „Aviacijos varikliai“. Ltn. J. Mikènas dvejus metus tarnavo aviacijos mechaniku ir buvo geras variklių remonto specialistas. 1923-1928 m. jis dalyvavo išbandant Lietuvos karo aviacijos ịsigytus lèktuvus Italijoje, be to, išvertẻ Fiat lèktuvų variklių priežiūros taisykles. 1939 m. „Skraidymo vadovèli“" parengè specialius skraidymo kursus baigęs ir didžiausią skraidymo instruktoriaus patirtị turintis plk. Česlovas Januškevičius. Du vadovėlius parengė Karo aviacijos mokyklos viršininkas plk. ltn. V. Reimontas, 1931 m. Italijoje baigęs Aukštuosius karo aviacijos kursus. Kartu su vadovèliais taip pat pradètos dažniau naudoti įvairios vaizdinès priemonès (brèžiniai ir schemos) ${ }^{140}$ ir su aviacijos tarnyba susiję statutai ${ }^{141}$.

5 lentelè. 1932-1940 m. išleistos pradinio teorinio rengimo mokomosios priemonès

\begin{tabular}{|c|c|c|c|c|}
\hline Pavadinimas & Autorius & $\begin{array}{l}\text { Išlei- } \\
\text { dimo } \\
\text { metai }\end{array}$ & Leidèjas & $\begin{array}{c}\text { Tiražas, leidybos } \\
\text { būdas }\end{array}$ \\
\hline $\begin{array}{l}\text { Aviacijos } \\
\text { varikliai }\end{array}$ & $\begin{array}{l}\text { Ltn. Jonas } \\
\text { Mikėnas }\end{array}$ & $1934 \mathrm{~m}$. & $\begin{array}{l}\text { Kariuomenės vyr. } \\
\text { štabo Spaudos ir } \\
\text { švietimo skyrius }\end{array}$ & $\begin{array}{l}\text { 1000, „Spindulio“ } \\
\text { spaustuvė }\end{array}$ \\
\hline $\begin{array}{l}\text { Bombur } \\
\text { mètymas }\end{array}$ & $\begin{array}{c}\text { Mjr. Viktoras } \\
\text { Reimontas }\end{array}$ & $1934 \mathrm{~m}$. & $\begin{array}{l}\text { Kariuomenės vyr. } \\
\text { štabo Spaudos ir } \\
\text { švietimo skyrius }\end{array}$ & 500, N. D. \\
\hline $\begin{array}{c}\text { Pilotažo } \\
\text { vadovėlis }\end{array}$ & $\begin{array}{c}\text { Plk. Antanas } \\
\text { Gustaitis }\end{array}$ & $1936 \mathrm{~m}$. & N. D. & $\begin{array}{l}\text { N. D., atspausdinta } \\
\text { dauginimo prietaisu }\end{array}$ \\
\hline $\begin{array}{l}\text { Tarptautinè ir } \\
\text { Lietuvos oro } \\
\text { teisé }\end{array}$ & $\begin{array}{c}\text { Mjr. Antanas } \\
\text { Špokevičius }\end{array}$ & $1937 \mathrm{~m}$. & $\begin{array}{l}\text { Karo aviacijos } \\
\text { mokykla }\end{array}$ & $\begin{array}{l}\text { N. D., atspausdinta } \\
\text { dauginimo prietaisu }\end{array}$ \\
\hline Lèktuvų statika & N. D. & N. D. & $\begin{array}{c}\text { Karo aviacijos } \\
\text { mokykla }\end{array}$ & $\begin{array}{l}\text { N. D., atspausdinta } \\
\text { dauginimo prietaisu }\end{array}$ \\
\hline $\begin{array}{l}\text { Skridimo } \\
\text { mechanika }\end{array}$ & $\begin{array}{c}\text { Plk. Antanas } \\
\text { Gustaitis }\end{array}$ & $1937 \mathrm{~m}$. & $\begin{array}{c}\text { Karo aviacijos } \\
\text { mokykla }\end{array}$ & $\begin{array}{l}\text { N. D., atspausdinta } \\
\text { dauginimo prietaisu }\end{array}$ \\
\hline
\end{tabular}

${ }^{140}$ Karo aviacijos mokyklos viršininko 1938 m. spalio 7 d. raštas Nr. 194 Karo aviacijos dirbtuvių viršininkui. LCVA, f. 1451, ap. 3, b. 54, 1. 60.

${ }^{141}$ Aviacijos naikintuvu statutas Av-55, Kaunas, 1937; Žvalgomosios aviacijos statutas Av-58. Kaunas, 1939; Aviacijos daliu stovejimo vietos ir žygiai. Aviacijos lauko tarnybos statutas Av-3. Kaunas, 1932; Artilerijos ir aviacijos bendradarbiavimo statutas A-56. Kaunas, 1937. 


\begin{tabular}{|c|c|c|c|c|}
\hline $\begin{array}{l}\text { Avigacijos } \\
\text { vadovèlis }\end{array}$ & $\begin{array}{c}\text { Plk. ltn. } \\
\text { Viktoras } \\
\text { Reimontas }\end{array}$ & $1938 \mathrm{~m}$. & $\begin{array}{l}\text { Kariuomenès } \\
\text { štabo Spaudos ir } \\
\text { švietimo skyrius }\end{array}$ & $\begin{array}{l}\text { 1000, „Spindulio“ } \\
\text { spaustuvė }\end{array}$ \\
\hline $\begin{array}{c}\text { Avigaciniai } \\
\text { žiroskopiniai } \\
\text { prietaisai }\end{array}$ & $\begin{array}{l}\text { Ltn. Leonas } \\
\text { Landsbergis }\end{array}$ & $1938 \mathrm{~m}$ & $\begin{array}{l}\text { Kariuomenès } \\
\text { štabo Spaudos ir } \\
\text { švietimo skyrius }\end{array}$ & $\begin{array}{l}\text { 500, „Spindulio“ } \\
\text { spaustuvė }\end{array}$ \\
\hline $\begin{array}{l}\text { Šviesinis } \\
\text { taikytuvas }\end{array}$ & N. D. & $1938 \mathrm{~m}$. & $\begin{array}{l}\text { Kariuomenès } \\
\text { štabo Spaudos ir } \\
\text { švietimo skyrius }\end{array}$ & $\begin{array}{l}\text { 500, „Spindulio“ } \\
\text { spaustuvė }\end{array}$ \\
\hline $\begin{array}{l}\text { Skraidymo } \\
\text { vadovèlis }\end{array}$ & $\begin{array}{l}\text { Plk. Česlovas } \\
\text { Januškevičius }\end{array}$ & 1939 m. & $\begin{array}{l}\text { Kariuomenès } \\
\text { štabo Spaudos ir } \\
\text { švietimo skyrius }\end{array}$ & $\begin{array}{l}\text { 1000, „Spindulio“ } \\
\text { spaustuvė }\end{array}$ \\
\hline $\begin{array}{l}\text { Lèktuvinis } \\
\text { brauningo } \\
\text { kulkosvaidis } \\
35 \text { ir } 36\end{array}$ & N. D. & $1939 \mathrm{~m}$. & $\begin{array}{l}\text { Kariuomenès } \\
\text { štabo Spaudos ir } \\
\text { švietimo skyrius }\end{array}$ & $\begin{array}{l}\text { 1000, „Spindulio“ } \\
\text { spaustuvė }\end{array}$ \\
\hline
\end{tabular}

Lentelè sudaryta autoriaus pagal: Mikènas, J. Aviacijos varikliai. Kaunas, 1934, p. 1-193; Reimontas, V. Bombu mettymas. Kaunas, 1934, p. 1-222; Gustaitis, A. Pilotažo vadovélis. Kaunas, 1936, p. 1-118; Tarptautine ir Lietuvos oro teisè. LCVA, f. 1451, ap. 3, b. 46, 1. 1-16; Lèktuvu statika. LCVA, f. 1451, ap. 3, b. 48, 1. 1-13; Gustaitis, A. Skridimo mechanika, 1937 m. LCVA, f. 1451, ap. 3, b. 49, 1. 1-77; Reimontas, V. Avigacijos vadovelis. Kaunas, 1938, p. 1-395; Landsbergis, L. Avigaciniai žiroskopiniai prietaisai. Kaunas, 1938, p. 1-26; Karo aviacijos mokyklos viršininko 1938 m. birželio 14 d. raportas Nr. 733 Karo aviacijos viršininkui. LCVA, f. 1451, ap. 3, b. 54, 1. 46; Šviesinis taikytuvas. Kaunas, 1938, p. 1-27; Januškevičius, Č. Skraidymo vadovèlis. Kaunas, 1939, p. 1-154; Léktuvinis brauningo kulkosvaidis 35 ir 36. Kaunas, 1939, p. 1-120; Jakštas, P. Lietuvos karinè spauda 1918-1938. Mūsu žinynas, Nr. 11-12 (165-166), 1938, p. 823.

Pastaba. Atliekant tyrimą taip pat nustatytos dar kelios mokomosios priemonès (plk. ltn. Kazys Mikolajūnas, „Radiotechnikos konspektas“ ${ }^{{ }^{142}}$, nežinomo autoriaus parengtas „Aklojo skraidymo konspektas“"143 ir A. Gustaičio parengtas „Aerodinamikos konspektas ${ }^{\text {“144}}$ ), tačiau apie jas nerasta patikimų ir išsamiu duomenų. Dar dvi su aviacija susijusias mokomąsias priemones karo aviacijos karininkai parenge kitoms institucijoms: gen. ltn. J. Kraucevičius 1926 m. - Vy-

\footnotetext{
${ }^{142}$ Karo aviacijos mokyklos puskarininkių klasės lakūnų skyriaus V laidos mokymo programos vykdymas. LCVA, f. 1451, ap. 3, b. 38, 1. 2.

${ }^{143}$ Aklasis skraidymas. Kaunas, 1939, p. 1-8.

${ }^{144}$ Gustaitis, A. Aerodinamikos konspektas. Kaunas, 1924, p. 1-87, LAM, GEK 15526; Gamziukas, A. Antanas Norèjo Būti Ore. Kaunas, 1997, p. 112-113, 127.
} 
tauto Didžiojo karininkų kursuose naudotą „Aviacijos kurso konspektą “145, o lakūnų rengimui Lietuvos aeroklube naudotą „Aerodinamikos ir skridimo mechanikos konspektą" 1935 m. - plk. A. Gustaitis ${ }^{146}$.

Naujų, išsamių mokomųjų priemonių leidyba tiesiogiai buvo susijusi su teorinių disciplinų dėstytojais. Dažniausiai specialius vadovėlius parengdavo pradiniame teoriniame rengime ilgiau dalyvavę dėstytojai, kurie ir tarnyboje specializuodavosi konkrečioje srityje (pavyzdžiui, meteorologijoje). Vis dėlto skraidančiojo personalo pradiniame rengime dalyvavę dèstytojai gana dažnai keitèsi ir daugiau nei keletą metų tą pačią discipliną dèsčiusių dèstytojų buvo nedaug ${ }^{147}$. Taip pat pasitaikydavo, kad mokomajai priemonei parengti skirtas karininkas pavestos užduoties neŁvykdydavo $^{148}$. Pavyzdžiui, 1935 m. turejo būti išleistas pilotažo vadovèlis, taip pat parengti norminiai aviacijos ginkluotès ir šaudybos dokumentai ir mechanikams skirtas vadovèlis ${ }^{149}$. Iš suplanuotų dokumentų buvo parengtas tik pilotažo vadovèlis. Dèl šių dviejų priežasčių pradinio teorinio rengimo mokomųjų priemonių leidyba vyko chaotiškai ir gana lètai.

Ketvirtajame dešimtmetyje greta išsamių vadovèlių ir toliau plačiai buvo naudojami 1924 m. ir vẻliau išleisti ne tokie išsamūs paskaitų konspektai. Būtent jie iki pat ketvirtojo dešimtmečio antrosios pusès išliko pagrindinè pradinio teorinio rengimo priemone $\dot{e}^{150}$. Tik 1938-1939 m. karo aviacijos buvo išleisti svarbiausių pradinio teorinio rengimo disciplinų vadovèliai, bet didesnès ịtakos skraidančiojo personalo rengimui dèl prasidejusios SSRS okupacijos jie jau nespèjo padaryti.

${ }^{145}$ Kraucevičius, J. Aviacijos kurso konspektas. Kaunas, 1928, p. 1-19.

${ }^{146}$ Gustaitis, A. Aviacijos teorijos konspektas. Aerodinamika ir skridimo mechanika. Kaunas, 1935, p. 1-66.

${ }^{147}$ Karo aviacijos mokyklos viršininko 1938 m. spalio 5 d. raportas Nr. 1376 Karo aviacijos viršininkui. $L C V A$, f. 1451 , ap. 3, b. 54, 1. 58; Karo aviacijos mokyklos viršininko 1938 m. spalio 11 d. raportas Nr. 1408 Karo aviacijos viršininkui. LCVA, f. 1451, ap. 3, b. 54, 1. 62; Karo aviacijos mokyklos viršininko 1939 m. rugsèjo 12 d. raportas Nr. 950 Karo aviacijos viršininkui. $L C V A$, f. 1451 , ap. 3, b. 38, 1. 34; Karo aviacijos viršininko 1937 m. gruodžio 4 d. raportas Nr. 3486 Kariuomenès vadui. $L C V A$, f. 1451, ap. 3, b. 29, 1. 5.

${ }^{148}$ Karo aviacijos mokyklos viršininko 1934 m. lapkričio 8 d. raportas Nr. 89/sl Karo aviacijos viršininko padejejui. $L C V A$, f. 1451 , ap. 3, b. 13, 1.3

${ }^{149}$ Kasparaitè-Balaišè, L. Lietuvos kariuomenès kovos statutai XX a. 3-4 dešimtmetyje. Karo archyvas, t. XXXIII, 2018, p. 239-240.

${ }^{150}$ Karo aviacijos mokyklos puskarininkių klasės lakūnų skyriaus IV laidos mokymo programos vykdymas. LCVA, f. 1451, ap. 3, b. 29, 1. 12; 
1932 m. parengta pirma abstrakti pradinio praktinio rengimo lakūnų puskarininkiu programa buvo detalizuota $1934 \mathrm{~m}$. bendroje karo aviacijos skraidančiojo personalo rengimo programoje. Pirmąji savarankišką skrydị būsimieji lakūnai atlikdavo su instruktoriais išskraidę 13-15 val. ${ }^{151}$ Nuo 1934 m. ì pradini praktinị rengimą buvo ịtrauktas aukštojo pilotažo mokymas, kuris anksčiau buvo vykdomas antrojoje pakopoje ${ }^{152}$. Kokybinis pradinio praktinio rengimo pokytis įvyko $1936 \mathrm{~m}$. atnaujinus ir išplètus pradinio rengimo skraidymo programą. I ją ịtrauktas skraidymo tik pagal prietaisus mokymas, taip pat skirta daugiau dèmesio ne vien skraidymo technikai, bet ir jos taikymui vykdant kovines užduotis. Pradiniam praktiniam rengimui buvo skirta 140 val., iš jų 25 val. skrydžiams su instruktoriumi, 80 val. lavinimuisi, o 35 val. aukštojo pilotažo mokymui ir užduočių vykdymui. Po apytiksliai 15-18 val. skrydžių su instruktoriais karys atlikdavo pirmąji savarankišką skrydį ${ }^{153}$.

Išanalizavus 1936-1939 m. Karo aviacijos mokykloje skraidyti mokytų 93 karių mokymo duomenis nustatyta, kad po pirmojo savarankiško skrydžio, instruktorių vertinimu, 44 kariai toliau rengti pagal lakūnams skirtą mokymo programą, 16 - pagal oro žvalgų programą. 27 iš 93 pašalinti kaip nepažangūs ar aviacijos tarnybai neturintys reikalingų gabumų, dar 2 pašalinti dèl drausmès pažeidimų ir lèktuvų apgadinimo ${ }^{154}$.

${ }^{151}$ Rimas, K. Kpt. K. Rimas prisimena... Plieno sparnai, Nr. 4, 1973 [žiūrèta 202001 15]. Prieiga per internetą: <http://www.plienosparnai.lt/page.php?544>

${ }^{152}$ Karo aviacijos lekiojančio personalo mokymas. LCVA, f. 1451, ap. 3, b. 36, 1. 21-49.

${ }^{153}$ Karo aviacijos mokyklos puskarininkių klasès lakūnų skyriaus IV laidos skraidymo mokymas. LCVA, f. 1451, ap. 3, b. 29, 1. 36; Karo aviacijos mokyklos puskarininkių klasès lakūnų skyriaus V laidos skraidymo mokymas. $L C V A$, f. 1451, ap. 3, b. 38, 1. 30.

${ }^{154}$ Lakūnų mokinių skraidymo mokymo žinių knygutès - A, B, C, Č. LCVA, f. 1451, ap. 1, b. 92; Lakūnų mokinių skraidymo mokymo žinių knygutès - D. LCVA, f. 1451, ap. 1, b. 93, l. nenumeruoti; Lakūnų mokinių skraidymo mokymo žinių knygutès - K. LCVA, f. 1451, ap. 1, b. 96, 1. nenumeruoti; Lakūnų mokinių skraidymo mokymo žinių knygutès - L. LCVA, f. 1451, ap. 1, b. 97, 1. nenumeruoti; Lakūnų mokinių skraidymo mokymo žinių knygutès - M. LCVA, f. 1451, ap. 1, b. 98, l. nenumeruoti; Lakūnų mokinių skraidymo mokymo žinių knygutès - O, P. LCVA, f. 1451, ap. 1, b. 100, 1. nenumeruoti; Lakūnų mokinių skraidymo mokymo žinių knygutès - S, Š. LCVA, f. 1451, ap. 1, b. 102, 1. nenumeruoti; Lakūnų mokinių skraidymo mokymo žinių knygutès - V, Z, Ž. LCVA, f. 1451, ap. 1, b. 104, l. nenumeruoti; Lakūnų mokinių skraidymų ịvertinimo knygutès - K, L. LCVA, f. 1451, ap. 1, b. 108, 1. nenumeruoti. 
Siekiant patobulinti, atpiginti ir pagreitinti pradini praktinị rengimą, buvo bandomos ịvairios naujovès. Lietuvos aeroklubui pasiūlius ${ }^{155}$, Karo aviacijos mokyklos puskarininkių klasės lakūnų skyriaus V laidos 37 mokiniai kandidatai 1938 m. balandžio 20-gegužès 20 d. Nidos sklandymo mokykloje mokèsi sklandyti ${ }^{156}$. Buvo tikimasi, kad mokymasis sklandyti sutrumpins pradinę praktinio rengimo pakopą ir būsimieji lakūnai greičiau Karo aviacijos mokykloje išmoks savarankiškai skraidyti. Per ménesị mokiniai kandidatai išklausė 10 val. teorinị kursą ir kiekvienas vidutiniškai atliko po 38 mokomuosius skrydžius. Buvo tikimasi, kad visi mokiniai kandidatai įvykdys „B“ piloto sklandytojo reikalavimus (sklandytuvą guminiu amortizatoriumi išvilkus, nenutūpę ore išbus $1 \mathrm{~min}$. ir tai atliks penkis kartus). Šiuos reikalavimus pavyko įvykdyti šiek tiek daugiau kaip pusei (22 iš 37) mokinių kandidatų ${ }^{157}$. I Nidos sklandymo mokyklą mokinius kandidatus lydejęs Karo aviacijos mokyklos skraidymo instruktorius kpt. Juozas Seliokas savo atsiminimuose teigè, kad „mokiniai grįže atgal vis tiek turèjo daug skraidyti lèktuvais, kad galètu savarankiškai skristi. Sklandymas davė šiek tiek naudos, bet ne tiek, kiek tikètasi" ${ }^{158}$. Sklandymo mokymus baigęs $\mathrm{V}$ laidos mokinys lakūnas gr. Juozas Mikutis taip pat kritiškai ịvertino šią praktinio rengimo naujovę: „Pasirodo, lekktuvu skristi gerokai sudetingiau negu sklandytuvu ir nedaug tebuvo naudos motoriniam skraidymui iš tu Nidos kopu. " ${ }^{159}$

\footnotetext{
${ }^{155}$ Lietuvos aeroklubo pirmininko $1937 \mathrm{~m}$. lapkričio 18 d. raštas Nr. 2652 Karo aviacijos mokyklos viršininkui. LCVA, f. 1451, ap. 3, b. 35, 1. 66.

${ }^{156}$ Karo aviacijos mokyklos mokiniams-kandidatams sklandymo mokymui išeiti ìsakymas, 1938 m. balandžio 7 d. LCVA, f. 1451, ap. 3, b. 54, 1. 32 .

${ }^{157}$ Karo aviacijos mokyklos kpt. Juozo Selioko 1938 m. gegužès 30 d. raportas Nr. 9 Mokomosios grupès vadui. LCVA, f. 1451, ap. 3, b. 54, 1. 43-44.

${ }^{158}$ Seliokas, J. Karo lakūno odisèja. Plieno sparnai, Nr. 5, 1998, p. 62.

${ }^{159}$ Mikutis, A. Lietuvos karo aviacijos tarnyboje 1936-1940. Plieno sparnai, Nr. 1, 1992, p. 27.
} 
6 lentelè. 1930-1940 m. pradiniam praktiniam rengimui naudoti lèktuvai

\begin{tabular}{|c|c|c|c|c|c|c|c|c|c|c|c|}
\hline $\begin{array}{l}\text { Lèktuvo } \\
\text { modelis }\end{array}$ & $\begin{array}{l}\dot{\Xi} \\
\text { ळ } \\
\text { ळ }\end{array}$ & $\frac{\dot{\Xi}}{\infty}$ & $\begin{array}{l}\dot{\Xi} \\
\text { } \\
\text { }\end{array}$ & $\begin{array}{l}\dot{\Xi} \\
\stackrel{2}{\sigma}\end{array}$ & $\begin{array}{l}\dot{\Xi} \\
\stackrel{\varpi}{\sigma}\end{array}$ & $\begin{array}{l}\dot{\Xi} \\
\tilde{\omega} \\
\text { ă }\end{array}$ & $\begin{array}{l}\dot{\Xi} \\
\mathscr{0} \\
\end{array}$ & $\begin{array}{l}\dot{\Xi} \\
\hat{\Omega} \\
\text { ڤ }\end{array}$ & $\begin{array}{l}\dot{\Xi} \\
\infty \\
\stackrel{\sigma}{\sigma}\end{array}$ & $\begin{array}{l}\dot{\Xi} \\
\text { ळે }\end{array}$ & $\begin{array}{l}\text { घं } \\
\text { 유 }\end{array}$ \\
\hline Alb. B. II & 3 & 3 & 2 & 2 & 2 & & & & & & \\
\hline Alb. C. I & 3 & 2 & 2 & 2 & 2 & & 2 & & & & \\
\hline Alb. C. III & 4 & 4 & 4 & 4 & 3 & & 3 & & & & \\
\hline Foker D.VII & 5 & 4 & 4 & 4 & 2 & 2 & 2 & 2 & 2 & 2 & 1 \\
\hline ANBO II & 1 & & & & & & & & & & \\
\hline ANBO III & 5 & 9 & 9 & 7 & 7 & 7 & 6 & 6 & 6 & 5 & 5 \\
\hline ANBO V & & 3 & 5 & 5 & 5 & 5 & 5 & 5 & 5 & 4 & 4 \\
\hline ANBO VI & 2 & 2 & & 2 & 4 & 4 & 4 & 3 & 3 & 3 & 3 \\
\hline ANBO 51 & & & & & & & & 5 & 8 & 11 & 10 \\
\hline $\begin{array}{l}\text { Bucker-133 C } \\
\text { „Jungmeister“ }\end{array}$ & & & & & & & & & & 3 & 6 \\
\hline $\begin{array}{l}\text { De Haviland } 89 \text { A } \\
\text { „Dragon Rapide“ }\end{array}$ & & & & & & & & & 2 & 2 & 2 \\
\hline AVRO 626 & & & & & & & & & 1 & 1 & 2 \\
\hline Iš viso: & 23 & 27 & 26 & 26 & 25 & 18 & 22 & 21 & 27 & 31 & 33 \\
\hline
\end{tabular}

Lentelè parengta autoriaus pagal: Kiek ir kokių lèktuvų buvo sausio mėn. $1 \mathrm{~d}$. LCVA, f. 1323, ap. 1, b. 601, 1. 8 .

Nuo 1932 m. pradinio praktinio rengimo pakopoje plačiau pradèti naudoti Karo aviacijos dirbtuvèse pastatyti inž. A. Gustaičio konstrukcijos mokomieji ir lavinimuisi skirti lèktuvai (žr. 6 lentelę). Galiausiai 1934 m. atsisakyta pradiniam praktiniam lakūnų rengimui naudoti $\mathrm{Al}$ batros tipo mokomuosius ir tolesniam lavinimuisi skirtus lèktuvus. Šiu lèktuvų visų pirma atsisakyta dèl ypač blogos jų būklès, taip pat dèl pilotavimo specifikos (ypač tupiant): jų naudojimas buvo sunkiai suderinamas su XX a. 4 dešimtmetyje karo aviacijoje pradètais eksploatuoti lèktuvais ${ }^{160}$. Nuo $1934 \mathrm{~m}$. lakūnai pradinio rengimo metu apie 15 val. su instruktoriumi mokydavosi skraidyti lekktuvu ANBO V, o po pirmo-

\footnotetext{
${ }^{160}$ Karo aviacijos mokomosios eskadrilès vado $1934 \mathrm{~m}$. liepos 7 d. raportas Nr. 37 Karo aviacijos mokyklos viršininkui. LCVA, f. 1451, ap. 3, b. 13, 1. 22.
} 
jo savarankiško skrydžio toliau treniruodavosi skraidydami ANBO III ir ANBO VI. Kokybinis pokytis ịvyko tik 1936-1937 m. pradiniam praktiniam rengimui pradèjus naudoti mokomąji lèktuvą ANBO 51 ir ị tolesnị rengimą ịtraukus daugiau lavinimuisi skirtų lèktuvų. Aukštojo pilotažo mokymui ir toliau naudotas Pirmojo pasaulio karo laikų Foker D. VII ${ }^{161}$.

7 lentelè. 1932-1940 m. pradiniame praktiniame rengime dalyvavę skraidymo instruktoriai

\begin{tabular}{|c|c|}
\hline $\begin{array}{l}\text { Pradinio praktinio } \\
\text { rengimo institucija }\end{array}$ & Rengime dalyvavę skraidymo instruktoriai \\
\hline $\begin{array}{l}\text { Karo aviacijos mokyklos } \\
\text { puskarininkių lakūnų } \\
\text { I laida, } 1934 \mathrm{~m} .\end{array}$ & $\begin{array}{l}\text { Kpt. Eugenijus Kraucevičius, kpt. Juozas Jankauskas, } \\
\text { kpt. Antanas Kutka, kpt. Jonas Liorentas, kpt. Jonas } \\
\text { Adomaitis, kpt. Narcizas Ferensas, ltn. Vytautas Čemarka }\end{array}$ \\
\hline $\begin{array}{l}\text { Karo aviacijos mokyklos } \\
\text { kadro karininkų kursų } \\
1935 \text { m. I laida }\end{array}$ & $\begin{array}{l}\text { Mjr. Č. Januškevičius, kpt. V. Čemarka, kpt. Vitalis } \\
\text { Milevičius, ltn. Simas Mockūnas, ltn. Juozas Vaičius, } \\
\text { ltn. Alfonsas Barzdys, j. ltn. Juozas Andriušis }\end{array}$ \\
\hline $\begin{array}{l}\text { Karo aviacijos mokyklos } \\
\text { kadro karininkų kursų } \\
1935 \text { m. II laida } \\
\end{array}$ & $\begin{array}{l}\text { Ltn. J. Vaičius, ltn. Balys Brazys, kpt. V. Milevičius, } \\
\text { j. ltn. J. Andriušis, vrš. Petras Kreivys }\end{array}$ \\
\hline $\begin{array}{l}\text { Karo aviacijos mokyklos } \\
\text { puskarininkių lakūnų } \\
\text { II laida, } 1937 \mathrm{~m} \text {. } \\
\end{array}$ & $\begin{array}{l}\text { Mjr. Č. Januškevičius, kpt. V. Čemarka, ltn. J. Vaičius, } \\
\text { ltn. B. Brazys, kpt. V. Milevičius, } \\
\text { j. ltn. J. Andriušis, vrš. P. Kreivys }\end{array}$ \\
\hline $\begin{array}{l}\text { Karo aviacijos mokyklos } \\
\text { kadro karininkų kursų } \\
1937 \text { m. laida } \\
\end{array}$ & $\begin{array}{l}\text { Kpt. A. Kutka, kpt. J. Vaičius, mjr. E. Kraucevičius, } \\
\text { ltn. Kazys Rimas, j. ltn. Leonas Lendraitis }\end{array}$ \\
\hline $\begin{array}{l}\text { Karo aviacijos mokyklos } \\
\text { puskarininkių lakūnų } \\
\text { III laida, } 1938 \mathrm{~m} \text {. }\end{array}$ & $\begin{array}{l}\text { Mjr. Č. Januškevičius, kpt. kpt. E. Kraucevičius, } \\
\text { kpt. A. Kutka, kpt. J. Vaičius, kpt. V. Milevičius, } \\
\text { j. ltn. J. Andriušis, j. ltn. L. Lendraitis, vrš. Motiejus } \\
\text { Garunkštis, vrš. Aleksandras Vachauzas, vrš. P. Kreivys, } \\
\text { vyr. psk. Povilas Vintis }\end{array}$ \\
\hline $\begin{array}{l}\text { Karo aviacijos mokyklos } \\
\text { puskarininkių lakūnų } \\
\text { IV laida, } 1939 \mathrm{~m} . \\
\end{array}$ & $\begin{array}{l}\text { Mjr. E. Kraucevičius, kpt. A. Kutka, kpt. J. Vaičius, } \\
\text { ltn. K. Rimas, psk. Romas Mažonas, psk. P. Vintis, } \\
\text { psk. Pranas Kuosaitis, psk. Viktoras Zizas }\end{array}$ \\
\hline $\begin{array}{l}\text { Karo aviacijos mokyklos } \\
\text { puskarininkių lakūnų } \\
\text { V laida, } 1940 \mathrm{~m} .\end{array}$ & $\begin{array}{c}\text { Vrš. M. Garunkštis, psk. R. Mažonas, } \\
\text { psk. P. Vintis, psk. Balys Dabušis, psk. Kazys Klimas, } \\
\text { psk. Edmundas Lparskas, } \\
\text { psk. Kostas Liuberskis, kpt. Juozas Seliokas }\end{array}$ \\
\hline
\end{tabular}

${ }^{161}$ Karo aviacijos mokyklos puskarininkių klasės lakūnų skyriaus IV laidos skraidymo mokymas. LCVA, f. 1451, ap. 3, b. 29, 1. 36; Karo aviacijos mokyklos puskarininkių klasès lakūnų skyriaus V laidos skraidymo mokymas. LCVA, f. 1451, ap. 3, b. 38, 1. 30. 
Lentelè parengta autoriaus pagal: Aviacijos viršininko 1932 m. spalio 26 d. raportas Nr. 5025 Vyriausiojo štabo viršininkui. LCVA, f. 1451, ap. 3, b. 6, 1. 8; Karo aviacijos mokyklos karininkų kursų 1934-1935 mokslo metų mokymo plano vykdymo tikrinimas. $L C V A$, f. 1451, ap. 3, b. 14, 1. 13; Karo aviacijos mokyklos puskarininkių lakūnų klasès lektorių sąrašas. $L C V A$, f. 1451, ap. 3, b. 15, 1. 9; Jaun. Itn. Navicko Antano skraidymo užrašų knygutè. LCVA, f. 531, ap. 1, b. 340, 1. 9-28; Karo aviacijos mokyklos puskarininkių lakūnų klasės lektorių sąrašas. LCVA, f. 1451, ap. 3, b. 22, 1. 6; Mikutis, A. Lietuvos karo aviacijos tarnyboje 1936-1940. Plieno sparnai, Nr. 1, 1992, p. 27.

1925-1935 m. skraidymo instruktoriais buvo paskirti ne mažiau kaip 17 karo lakūnų ir naudojant atkritimo strategiją ypač aktyviai ieškant tinkamiausių instruktorių eksperimentuota 1930-1935 m. (žr. 7 lentelę). Šio laikotarpio pabaigoje susiformavo nuolatinių instruktorių grupė, kurią sudarè mjr. Č. Januškevičius, kpt. Eugenijus Kraucevičius, ltn. Vytautas Čemarka, kpt. Vitalis Milevičius, ltn. Juozas Vaičius, j. ltn. Juozas Andriušis ir kpt. Antanas Kutka. Prasčiau pasirodę karo lakūnai nebuvo skiriami pakartotinai skraidymo instruktoriais ir tęsdavo tarnybą kovinèse eskadrilèse. Minètų skraidymo instruktorių kompetencijų ugdymas daugiausia rèmési mokymosi iš klaidų metodu. Kitaip tariant, visi Lietuvos karo aviacijos instruktoriai buvo savamoksliai ir neturejo specialaus instruktoriams aktualaus išsilavinimo.

Situacija reikšmingai pasikeitè mjr. Č. Januškevičiui grị̌žus iš kursų Jungtinèje Karalystèje. Didžiausią patirtị mokant lakūnus turintis mjr. Č. Januškevičius Jungtinejje Karalystejje 1934 m. baigè skraidymo ir aklojo pilotavimo instruktorių kursus. Jam vadovaujant Karo aviacijos mokykloje 1936 m. sausio 1-gegužès 15 d. organizuoti pirmieji skraidymo instruktorių kursai, kurių pagrindinis tikslas buvo suteikti metodinių žinių, būtinų mokantiems skraidyti ${ }^{162}$. Planuota, kad iki $1936 \mathrm{~m}$. vasaros pradžios mjr. Č. Januškevičius ir jo kiek anksčiau apmokytas kpt. Juozas Vaičius parengs 8 skraidymo instruktorius ${ }^{163}$. Preliminariais duomenimis, $1936 \mathrm{~m}$. pavasari parengti 6 instruktoriai mokè skraidyti Karo aviacijos mokyklos

\footnotetext{
${ }^{162}$ Skraidymo instruktorių paruošimo mokymo planas. LCVA, f. 1451, ap. 3, b. 33, 1. 2.

${ }^{163}$ Karo aviacijos mokyklos skraidymo instruktoriams paruošti lektorių sąrašas. LCVA, f. 1451 , ap. 3, b. $33,1.5$.
} 
puskarininkių lakūnų skyriaus III laidos lakūnus ${ }^{164}$. Iki SSRS okupacijos kiekvienais metais organizuojami skraidymo instruktorių kursai buvo periodiškai tobulinami (žr. 8 lentelę). 1936-1939 m. planuota parengti 30 naujų skraidymo instruktorių ir patobulinti 9 instruktorių igūdžius. Vis dèlto labai tikètina, kad užsibrèžtas tikslas nebuvo pasiektas, nes 1936-1938 m. iš programose mokymui numatytų 535 val. buvo išnaudotos tik 363 val.

8 lentelè. Lietuvos karo aviacijos 1936-1939 m. skraidymo instruktorių kursai

\begin{tabular}{|c|c|c|c|c|c|}
\hline $\begin{array}{c}\text { Skraidymo } \\
\text { instruktorių } \\
\text { kursai }\end{array}$ & $\begin{array}{l}\text { Mokymo } \\
\text { programos } \\
\text { apimtis, } \\
\text { val. }\end{array}$ & $\begin{array}{c}\text { Planuota } \\
\text { parengti } \\
\text { instruktorių }\end{array}$ & $\begin{array}{l}\text { Mokymui } \\
\text { skirtų } \\
\text { valandų } \\
\text { skaičius }\end{array}$ & $\begin{array}{l}\text { Mokymui } \\
\text { išnaudotų } \\
\text { valandų } \\
\text { skaičius } \\
\end{array}$ & Instruktoriai \\
\hline $\begin{array}{c}\text { Karo aviacijos } \\
\text { mokyklos } \\
\text { skraidymo } \\
\text { instruktorių } \\
\text { kursai, } \\
1936 \mathrm{~m} \text {. laida } \\
\end{array}$ & 15 & 8 & 120 & 80 & $\begin{array}{c}\text { Mjr. } \\
\text { Č. Januškevičus, } \\
\text { kpt. J. Vaičius }\end{array}$ \\
\hline $\begin{array}{c}\text { Karo aviacijos } \\
\text { mokyklos } \\
\text { skraidymo } \\
\text { instruktorių } \\
\text { kursai, } \\
1937 \text { m. laida } \\
\end{array}$ & $\begin{array}{c}25 \\
(10)^{*}\end{array}$ & $\begin{array}{c}3 \\
(10)^{\star}\end{array}$ & $\begin{array}{c}75 \\
(90)^{*}\end{array}$ & 139 & $\begin{array}{c}\text { Plk. ltn. } \\
\text { Č. Januškevičus, } \\
\text { mjr. E. Krau- } \\
\text { cevičius, } \\
\text { kpt. J. Vaičius }\end{array}$ \\
\hline $\begin{array}{c}\text { Karo aviacijos } \\
\text { mokyklos } \\
\text { skraidymo } \\
\text { instruktorių } \\
\text { kursai, } \\
1938 \mathrm{~m} \text {. laida }\end{array}$ & 25 & 10 & 250 & 144 & $\begin{array}{c}\text { Plk. ltn. } \\
\text { Č. Januškevičus, } \\
\text { kpt. J. Vaičius, } \\
\text { vrš. M. Garunkštis }\end{array}$ \\
\hline $\begin{array}{c}\text { Karo aviacijos } \\
\text { mokyklos } \\
\text { skraidymo } \\
\text { instruktorių } \\
\text { kursai, } \\
1939 \mathrm{~m} \text {. laida }\end{array}$ & 25 & 5 & 125 & ND & Nenustatyta \\
\hline
\end{tabular}

${ }^{164}$ Karo aviacijos mokyklos puskarininkių lakūnų klasės lektorių sąrašas. LCVA, f. 1451, ap. 3, b. 22, l. 6; Karo aviacijos mokyklos $1936 \mathrm{~m}$. skraidymo instruktoriams paruošti dėstomųjų dalykų suskirstymas kategorijomis. LCVA, f. 1451, ap. 3, b. 33, 1. 2. 
Lentele sudaryta autoriaus pagal: Karo aviacijos mokyklos skraidymo instruktorių paruošimo mokymo planas 1936 m. LCVA, f. 1451, ap. 3, b. 33, 1. 1-7; Karo aviacijos mokyklos skraidymo instruktoriams paruošti mokymo planas 1937 m. LCVA, f. 1451, ap. 3, b. 44, 1. 1-7; Karo aviacijos mokyklos skraidymo instruktoriams paruošti mokymo planas 1938 m. LCVA, f. 1451, ap. 3, b. 62, 1. 1-5; Karo aviacijos mokyklos skraidymo instruktoriams paruošti mokymo planas 1939 m. LCVA, f. 1451, ap. 3, b. 78, 1. 1-3;

${ }^{\star}$ Pastaba. $1937 \mathrm{~m}$. taip pat numatyta patobulinti 9 skraidymo instruktoriu igūdžius, skiriant kiekvienam po 10 val.

1937-1940 m. buvo suformuota apie 10 instruktorių, turinčių ne trumpesnę nei trejų metų patirtị ir dalyvavusių daugiau kaip 20 lakūnų rengime, grupè. Taip pat jie buvo baigę skraidymo instruktorių kursus, o tai leido suvienodinti mokymo procesą ir užtikrinti, kad jo metu visiems būsimiems lakūnams bus suteiktos vienodos žinios ${ }^{165}$. Galima teigti, kad XX a. ketvirtojo dešimtmečio pabaigoje Karo aviacijos mokykloje jau tarnavo profesionalūs skraidymo instruktoriai, o jų pasirengimas reikšmingai skyrè nuo anksčiau skraidančiojo personalo rengime dalyvavusių karių pasirengimo.

Pirmąją rengimo pakopą baigusiems kariams buvo suteikiamas II rango karo lakūno vardas ir jie perkeliami ị kovines eskadriles. Kovinèse eskadrilès II rango karo lakūnai tęsdavo individualų rengimą, kuris, kaip ir anksčiau, priklausė nuo eskadrilès pobūdžio (naikintuvų, žvalgybos, bombonešių) ir kario profilio (pilotas ar oro žvalgas). Eskadrilèse II rango karo lakūnai vykdè 1934 m. patvirtintą skraidymo programą, kurią baigus ir apgynus teorinį darbą buvo suteikiamas I rango karo lakūno vardas ${ }^{166}$. Tuo pat metu II rango karo lakūnams taip pat buvo privaloma vykdyti kasmetes skraidymo programas, dalyvauti šaudymo pratybose ir kariuomenès manevruose ${ }^{167}$. Lakūnai, nebaigę skraidymo tik pagal prietaisus

${ }^{165}$ Karo aviacijos mokyklos skraidymo mokymo instruktorių sąrašas /1937-1939 m. m. laid./. LCVA, f. 1451, ap. 3, b. 29, 1. 9.

${ }^{166}$ Navaitis, A. Šimtmečio skrydis. Karo lakūno atsiminimai. Vilnius, 2017, p. 61-64.

${ }^{167}$ Karo aviacijos lekiojančio personalo mokymas. LCVA, f. 1451, ap. 3, b. 36, 1. 21-49. 
mokymų, šiuose mokymuose dalyvaudavo antrojoje rengimo pakopoje ${ }^{168}$. 1936-1939 m. buvo surengti ketveri kursai, tačiau $1940 \mathrm{~m}$. pavasari tik apie 15-20 proc. lakūnų buvo baigę skraidymo pagal prietaisus kursus ${ }^{169}$.

Suteikus I rango karo lakūno vardą, lakūnas tęsdavo individualų rengimą trečiojoje pakopoje, kuri buvo mažiausiai intensyvi ir daugiausia orientuota ị ankstesnèse pakopose igytų žinių ir ịūdžių palaikymą ir tobulinimą. Tai buvo igyvendinama vykdant kasmetes skraidymo ir šaudymo programas. Priešingai nei ankstesnių dviejų rengimo pakopų, trečiosios pakopos trukmé nebuvo apibrèžta, ir ji trukdavo tiek, kiek lakūnas tarnaudavo karo aviacijoje.

Nors ir standartizuotas, antrojo, o ypač trečiojo etapo metu skraidančiojo personalo rengimas nevyko sklandžiai. $1934 \mathrm{~m}$. užfiksuota, kad karo aviacijos daliniuose besitreniruojantys lakūnai vengè sudètingesnių pratimų, treniruotis žiemą ar blogomis oro sąlygomis ir daugumą pratimų atlikdavo vasarą ${ }^{170}$. Reaguojant ị pastebètus trūkumus, $1935 \mathrm{~m}$. numatyta rengiamą skraidymo programą suskirstyti $\mathfrak{i}$ keturis mokymo laikotarpius po 3 mèn. ir juose proporcingai paskirstyti visų tipų užduotis ${ }^{171}$. Taip pat prasidedant $1935 \mathrm{~m}$. skraidymo sezonui karo aviacijos vadovybe pastebejo, kad skraidančiojo personalo išskraidytų valandų skaičius labai netolygus (ivvairuoja nuo daugiau kaip 100 val. iki 30-40 val.). Reaguojant ì susidariusią situaciją buvo patvirtinti nauji minimalūs skraidymo krūviai: karo lakūnui pilotui naikintuvų eskadrileje numatyta 50 val., karo lakūnui pilotui kitose eskadrilèse - 60 val., karo lakūnui oro žvalgui kitose eskadrilèse - 40 val., mokiniui lakūnui pilotui - 90 val., o mokiniui

${ }^{168}$ Karo aviacijos mokyklos Aklojo pilotavimo mokymo planas 1936 m. LCVA, f. 1451, ap. 3, b. 32, 1. 1-7; Karo aviacijos mokyklos Aklojo pilotavimo apmokymo kursų mokymo planas 1937 m. LCVA, f. 1451, ap. 3, b. 42, 1. 1-8; Karo aviacijos mokyklos Aklojo pilotavimo mokymo kursų mokymo planas 1938 m. LCVA, f. 1451, ap. 3, b. 61, 1. 1-5; Karo aviacijos mokyklos Aklojo pilotavimo apmokymo kursų mokymo planas $1939 \mathrm{~m}$. LCVA, f. 1451, ap. 3, b. 77, 1. 1-5.

${ }^{169}$ Lesčius, V, Lietuvos kariuomenès organizavimo, dislokavimo ir ginkluotès pokyčiai 1938-1940 m. Karo archyvas, t. XXIV, 2009, p. 188-190.

${ }^{170}$ Karo aviacijos rikiuotès skyriaus $1934 \mathrm{~m}$. sausio 30 d. raštas Nr. 65 Aviacijos mokyklos viršininkui. $L C V A$, f. 1451, ap. 3, b. 13, 1. 35 .

${ }^{171}$ Karo aviacijos rikiuotès skyriaus 1935 m. sausio 25 d. raštas Nr. 455 Karo aviacijos mokyklos viršininkui. LCVA, f. 1451, ap. 3, b. 19, 1. 26. 
lakūnui žvalgui - 75 val. ${ }^{172}$

Antrosios arba trečiosios rengimo pakopos metu specialiųjų žinių ir igūdžių igyti keliolika karo aviacijos karininkų buvo komandiruoti arba pasiųsti stažuotis ị užsienio valstybes. Daugumos studijos nebuvos tiesiogiai susijusios su lèktuvo pilotavimu. Pavyzdžiui, ats. vyr. ltn. Jurgis Dobkevičius, vyr. ltn. Antanas Gustaitis, vyr. ltn. Vytautas Jablonskis, kpt. Antanas Gavelis ir ltn. Alfonsas Aušrūnas studijavo aviacijos inžineriją Aukštojoje aeronautikos ir mechaninių konstrukcijų mokykloje Paryžiuje, ltn. Bronius Oškinis ir j. ltn. Leonas Kinaitis Berlyno aukštojoje technikos mokykloje ${ }^{173}$ studijavo lèktuvų statybą, o kpt. Stasys Jakštys Belgijos Lježo politechnikos institute baigè elektrotechnikos studijas. 1927-1938 m. keturi aviacijos karininkai buvo išsiųsti studijuoti ị Italijos, Vokietijos ir Čekoslovakijos generalinio štabo akademijas, iš jų tik du tęsè tarnybą aviacijoje. $1925 \mathrm{~m}$. vyr. ltn. Vytautas Jablonskis, $1931 \mathrm{~m}$. kpt. Jonas Špokevičius baigè specialiuosius fotografijos kursus Paryžiuje. Kpt. Bronius Vaivada 1934 m. baige Strasbūro universiteto Geofizikos ir matematikos institutą ir 6 mèn. stažavosi Prancūzijoje meteorologijos srityje. 1919-1940 m. tik keturi aviacijos karininkai tobulino su skraidymu susijusias žinias ir igūdžius užsienio šalyse. 1930-1931 m. mjr. Viktoras Reimontas mokèsi Italijoje aukštuosiuose karo aviacijos kursuose ir stažavosi Italijos aviacijos daliniuose. $1932 \mathrm{~m}$. kpt. Jeronimas Garolis 6 mèn. stažavo Italijos karo aviacijoje, o 1934 m. mjr. Česlovas Januškevičius Jungtinejje Karalystėje baigè skraidymo ir aklojo pilotavimo instruktorių kursus. 1931 m. ltn. Grigorius Radvenis ne tarnybos metu Vokietijoje baigè Rasytės sklandymo mokyklą ${ }^{174}$.

\footnotetext{
${ }^{172}$ Karo aviacijos įsakymas Nr. 6/sl, 1935 m. birželio 11 d. LCVA, f. 1451, ap. 3, b. 20, 1. 8. ${ }^{173}$ Pastaba. 1939 m. ats. j. ltn. Julius Bulota Berlyno aukštojoje technikos mokykloje studijavo aeronautiką, tačiau šis atsargos karininkas Lietuvos karo aviacijoje netarnavo. 1939 m. su Krašto apsaugos ministerijos stipendija ị tą pačią mokyklą lèktuvų statybos studijuoti išvyko ats. j. ltn. Juozas Čepaitis, tačiau jis Karo aviacijos dirbtuvèse dirbo civiliu tarnautoju ir Karo aviacijoje skraidymo užduočių nevykdè.

174 Žigaras, F. Karininkų rengimo ir jų kvalifikacijos kèlimo sistema 1919-1940 m. II dalis. Vilnius. 2018, p. 222-238; Kulnytė, B. (et. al.) Lietuvos kariuomenés karininkai 19181953, t. III, Vilnius. 2003, p. 65-66; Kulnytè, B. (et. al.) Lietuvos kariuomenès karininkai 1918-1953, t. IV. Vilnius, 2004, p. 13; Kulnytè, B. (et. al.) Lietuvos kariuomenés karininkai 1918-1953, t. VI. Vilnius, 2006, p. 203-204.
} 


\section{SKRAIDANČIOJO PERSONALO RENGIMO SISTEMOS REZULTATYVUMAS IR PAKANKAMUMAS}

Dèl duomenų stokos nustatyti tikslų 1919-1940 m. Lietuvos karo aviacijoje skraidančiojo personalo rengimo sistemą baigusių karių skaičių sunku. Preliminariais duomenimis, 1919-1940 m. buvo parengti ne mažiau kaip 338 lakūnai ir oro žvalgai (žr. 9 lentelę). Tačiau dalis karių keletą kartų dalyvavo rengimo sistemoje, be to, ne visi baigę pradinį teorinio ir praktinio rengimo etapą tarnavo karo aviacijoje ir vykde su skraidymu susijusias užduotis. Iš 338 karių 305 pradinị teorinị ir praktinị rengimo etapą baigè vieną kartą ir toliau jị tęsé antrojoje pakopoje. Prie šio skaičiaus dar turètų būti pridèti 10 lakūnų ir oro žvalgų, kurie ị tarnybą buvo priimti iš rezervo. Trūkstant skraidančiojo personalo, jis buvo papildomas specialiai parengto rezervo kariais. 1919-1940 m. karo aviacijoje paraleliai veikè skraidančiojo personalo rezervo rengimo sistema. Oro žvalgų rezervas buvo formuojamas organizuojant tam skirtus kursus. 1933 m. šiuos kursus baigè 15 oro žvalgų, iš jų 3 vèliau dar baigè Karo aviacijos mokyklą ir tarnavo karo aviacijoje ${ }^{175} .1939 \mathrm{~m}$. kursų II laidą baigé 18 karių $^{176}$, iš jų 7, baigę kursus, buvo priimti ị tarnybą karo aviacijoje ${ }^{177}$. Lakūnų rezervas buvo formuojamas pasitelkiant Karo mokyklos aspirantų kursus, kuriuos iki $1940 \mathrm{~m}$. spalio mèn. baigè 58 aviacijos j. ltn. ${ }^{178}$, iš jų 3 buvo priimti i karo aviaciją ${ }^{179}$.

1921-1925 m. skraidančiojo personalo rengimo sistema tik iš dalies patenkino tuomečius poreikius. Karo aviacijos dirbtuvèse buvo pastatyti

\footnotetext{
${ }^{175}$ İsakymas kariuomenei Nr. 88, 1932 m. gruodžio 31 d.; I sakymas kariuomenei Nr. 75, 1933 m. spalio 25 d. [žiūrèta 2020-01-15]. Prieiga per internetą:<https://www.epaveldas. lt/vbspi/biSerial.do?bi RecordId=194362>

${ }^{176}$ Issakymas Karo aviacijai Nr. 89, 1939 m. rugsèjo 16 d. LCVA, f. 1323, ap. 1, b. 523, 1. 102. 177 Issakymas Karo aviacijai Nr. 71, 1940 m. rugpjūčio 21 d. LCVA, f. 1323, ap. 1, b. 594, 1. 41. ${ }^{178}$ Kulnyte, B. (et. al.) Lietuvos kariuomenes karininkai 1918-1953, t. III. Vilnius, 2003, p. 354-388.

${ }^{179}$ Kariuomenès vado ịsakymas Nr. 29, 1937 m. gruodžio 31 d.; Kariuomenės vado ịsakymas Nr. 24, 1938 m. lapkričio 7 d.; Kariuomenès vado ịsakymas Nr. 28, 1939 m. rugpjūčio 8 d. [žiūrèta 202001 15]. Prieiga per internetą: <https://www.epaveldas.lt/vbspi/biSerial. do?biRecordId $=2891>$
} 
nauji ir suremontuoti 49 trofëjiniai koviniai lèktuvai ${ }^{180}$. Taip pat dar 18 naujų lèktuvų ịsigyta iš Italijos ir Čekoslovakijos ${ }^{181}$. Per šị laikotarpi parengti 47 lakūnai ir oro žvalgai bei papildomai apmokyti 1919 m. Karo aviacijos mokyklos 12 absolventų (žr. 9 lentelę). Parengtų lakūnų stoka stabdè karo aviacijos plètrą ir dèl to nebuvo išnaudojamas visas turimas techninis potencialas. Pavyzdžiui, $1925 \mathrm{~m}$. pabaigoje dvi eskadrilès buvo beveik nesukomplektuotos - 1-ojoje eskadrilèje buvo tik 4 lakūnai182, o $1925 \mathrm{~m}$. rugpjūčio $1 \mathrm{~d}$. pradètai formuoti 4 -ajai eskadrilei ypač trūko lakūnų ${ }^{183}$.

1932 m. patvirtintuose atnaujintuose karo aviacijos taikos metų etatų sąrašuose buvo numatytas 81 skraidančiojo personalo etatas ${ }^{184}$. 19261932 m. buvo parengti 55 lakūnai ir oro žvalgai, o tai sudarè 68 proc. visų etatiniame sąraše numatytų skraidančiojo personalo karių. Pavyzdžiui, dviejose naikintuvų eskadrilèse buvo numatyta 18 lakūnų etatų, iš jų 1932 m. pabaigoje buvo užimta $15^{185}$. Todèl galima teigti, kad apie 1932 m. pavyko patenkinti didžiąją dalị buvusio poreikio.

1933-1939 m. karo aviacijoje buvo įsteigtos dvi naujos eskadrilès ir patvirtinti nauji taikos meto etatai, tarp jų ir reikšmingai padidejęs skraidančiojo personalo karių skaičius. Pavyzdžiui, 1932 m. naikintuvų eskadrilèje buvo numatyti 9 lakūnų etatai, o 1935 m. - jau 14 etatų ${ }^{186}$. Per ši laikotarpi daugiau kaip 20 lakūnų išèjo ị atsargą ir 9 žuvo aviakatastrofose. Skraidančiojo personalo poreiki pavyko patenkinti tik apie $1939 \mathrm{~m} .{ }^{187}$

1919-1940 m. skraidančiojo personalo rengimo sistemai nuolat tekdavo kompensuoti dèl įvairių priežasčių mažejanti parengtų karių skaičių. 1919-1940 m. aviakatastrofose žuvo 25 skraidančiojo personalo kariai, kurie buvo baige pirmąją praktinio ir teorinio rengimo pakopą. Dar 5 parengti kariai mirè nuo ligų ir sužeidimų, nesusijusių su tarnyba ${ }^{188}$. Po

\footnotetext{
${ }^{180}$ Ramoška, G. Pirmieji Lietuvos karo aviacijos lèktuvai. Plieno sparnai, Nr. 1, 1992, p. 2-7; Ramoška, G. Lèktuvai, pagaminti Kaune. Plieno sparnai, Nr. 4, 1997, p. 80.

${ }^{181}$ Gamziukas, A. Aviacija Lietuvoje 1919-1940. Kaunas, 1993, p. 16.

${ }^{182}$ Mikènas, J. Karo aviacijos pirmoji eskadrilè. Plieno sparnai, Nr. 1, 1992, p. 13.

${ }^{183}$ Pyragius, J. Kovosiu, kol gyvas. Kaunas, 1993, p. 37-38.

184 Aviacijos taikos meto etatai Nr. 74. LCVA, f. 509, ap. 1, b. 6, 1. 190-194.

${ }^{185}$ Mikènas, J. Karo aviacijos pirmoji eskadrilè. Plieno sparnai, Nr. 1, 1992, p. 14.

186 Karo aviacijos taikos meto etatai Nr. 95. LCVA, f. 531, ap. 1, b. 191, 1. 9.

${ }^{187}$ Karo aviacijos ịsakymas Nr. 2/sl, 1939 m. gegužès 19 d. LCVA, f. 1323, ap. 1, b. 261, 1. $2-3$.

${ }^{188}$ Lukšys, S., Mintautas, R., Monkevičius, J. Palūžę sparnai. Vilnius, 1997, p. 15-45.
} 
1934 m. voldemarininkų pučo iš karo aviacijos ị atsargą buvo išleista 16 karininkų, iš jų 15 lakūnų ir oro žvalgų ${ }^{189}$. Periodiškai i t atsargą išeidavo parengti kariai, pavyzdžiui, iš $1919 \mathrm{~m}$. Karo aviacijos mokyklos absolventų, kurie tarnavo lakūnais ar oro žvalgais, iki 1940 m. ị atsargą išèjo 13. Taip pat pasitaikydavo atvejų, kai pirmąją rengimo pakopą baigę kariai iškart buvo išleidžiami ị atsargą - $1934 \mathrm{~m}$. buvo parengti 24 lakūnai, iš juc 5 iš karto išleisti ị atsargą, 2 tęse tarnybą administracijoje ir neskraidè, o vienas po sužeidimų išleistas ị dimisiją ${ }^{190}$.

9 lentelè. Lietuvos karo aviacijoje 1919-1940 m. parengtų skraidančiojo personalo karių skaičius

\begin{tabular}{|c|c|c|}
\hline $\begin{array}{l}\text { Pradinio teorinio ir } \\
\text { praktinio rengimo institucija }\end{array}$ & Rengimo laikotarpis & $\begin{array}{c}\text { Parengtų } \\
\text { karių } \\
\text { skaičius }\end{array}$ \\
\hline Karo aviacijos mokyklos I laida, 1919 m. & $19190312-19191216$ & $34(22)^{*}$ \\
\hline 1920 m. Mokomojo būrio kursai & $19200901-19201231$ & N. D. \\
\hline $\begin{array}{l}1921 \text { m. Mokomosios eskadrilès } \\
\text { aviacijos kursai }\end{array}$ & $19210315-19210816$ & 11 \\
\hline $\begin{array}{l}1922 \text { m. Mokomosios eskadrilès } \\
\text { aviacijos kursai }\end{array}$ & $19220123-19220925$ & 10 \\
\hline $\begin{array}{l}\text { 1922-1923 m. Mokomosios } \\
\text { eskadrilès aviacijos kursai }\end{array}$ & $19221016-19230723$ & 7 \\
\hline $\begin{array}{l}\text { 1922-1923 m. Mokomosios } \\
\text { eskadrilès aviacijos kursai }\end{array}$ & $19231119-19240612$ & 17 \\
\hline $\begin{array}{c}\text { 1924-1925 m. Mokomosios } \\
\text { eskadrilès aviacijos kursai }\end{array}$ & $19241110-19250627$ & 14 \\
\hline $\begin{array}{l}\text { Vytauto Didžiojo karininkų kursų } \\
\text { aviacijos skyriaus I laida, } 1927 \mathrm{~m} .\end{array}$ & $19261108-19270714$ & 15 \\
\hline $\begin{array}{l}\text { Vytauto Didžiojo karininkų kursų } \\
\text { aviacijos skyriaus II laida, } 1930 \mathrm{~m} \text {. }\end{array}$ & $19280201-19300215$ & 9 \\
\hline $\begin{array}{l}\text { Mokomosios eskadrilès aviacijos kursai } \\
\text { puskarininkiams, } 1929 \text { m. }\end{array}$ & $19290115-19291220$ & $12(1)^{\star *}$ \\
\hline $\begin{array}{l}\text { Vytauto Didžiojo karininkų kursų } \\
\text { aviacijos skyriaus III laida, } 1932 \text { m. }\end{array}$ & $19300307-19320514$ & 19 \\
\hline $\begin{array}{l}\text { Karo aviacijos mokyklos puskarininkių } \\
\text { lakūnų I laida, } 1934 \mathrm{~m} .\end{array}$ & $19320501-19341101$ & $23(24)^{\star * *}$ \\
\hline
\end{tabular}

189 İsakymas Lietuvos kariuomenei Nr. 60, 1934 m. liepos 10 d. [žiūrèta 202001 15]. Prieiga per internetą:<https://www.epaveldas.lt/vbspi/biSerial.do?bi RecordId=194362> 190 Aviacijos štabo Puskarininkių lakūnų mokyklos mokinių abėcèlinè knyga. LCVA, f. 930 , ap. 7, b. $4439,1.1-194$. 


\begin{tabular}{|c|c|c|}
\hline $\begin{array}{c}\text { Karo aviacijos mokyklos kadro karininkų } \\
\text { kursu } 1935 \text { m. I laida }\end{array}$ & $19340831-19350720$ & 13 \\
\hline $\begin{array}{l}\text { Karo aviacijos mokyklos kadro } \\
\text { karininkų kursų } 1935 \text { m. II laida }\end{array}$ & $19340831-19351015$ & 11 \\
\hline $\begin{array}{l}\text { Karo aviacijos mokyklos puskarininkių } \\
\text { lakūnų II laida, } 1937 \text { m. }\end{array}$ & $19341120-19371030$ & $15(3)(1)^{\star * * *}$ \\
\hline $\begin{array}{l}\text { Karo aviacijos mokyklos kadro } \\
\text { karininkų kursų } 1937 \text { m. laida }\end{array}$ & $19360917-19371231$ & 15 \\
\hline Karo mokyklos XIX laida, 1938 m. & $19350901-19380512$ & $19(21)^{\star * * * *}$ \\
\hline $\begin{array}{c}\text { Karo aviacijos mokyklos puskarininkių } \\
\text { lakūnų III laida, } 1938 \mathrm{~m} \text {. }\end{array}$ & $19351101-19381031$ & $15(2)(3)^{* * * * * *}$ \\
\hline $\begin{array}{l}\text { Karo aviacijos mokyklos puskarininkių } \\
\text { lakūnų IV laida, } 1939 \mathrm{~m} .\end{array}$ & $19361101-19391031$ & 17 \\
\hline $\begin{array}{l}\text { Karo aviacijos mokyklos puskarininkių oro } \\
\text { šaulių kursų I laida, } 1939 \text { m. }\end{array}$ & $19390504-19391031$ & $11(5)^{\star * * * * * *}$ \\
\hline $\begin{array}{l}\text { Karo aviacijos mokyklos puskarininkių } \\
\text { lakūnų V laida, } 1940 \mathrm{~m} .\end{array}$ & $19371101-19401015$ & 14 \\
\hline Karo mokyklos XXI laida, 1940 m. & $19380901-19400819$ & $16(19)^{* * * * * * * *}$ \\
\hline
\end{tabular}

Lentelè sudaryta autoriaus pagal: İsakymas aviacijai Nr. 57, 1921 m. lapkričio 1 d. LCVA, f. 1323, ap. 1, b. 21, l. 56; Isakymas aviacijai Nr. 46, 1922 m. rugsèjo 25 d. LCVA, f. 1323, ap. 1, b. 44, 1. 49; İsakymas aviacijai Nr. 51, 1925 m. birželio 27 d. LCVA, f. 1323, ap. 1, b. 115, 1. 61; Itsakymas aviacijai Nr. 87, 1929 m. spalio 11 d. $L C V A$, f. 1323, ap. 1, b. 185, 1. 112; Isakymas aviacijai Nr. 101, 1929 m. gruodžio 21 d. LCVA, f. 1323, ap. 1, b. 185, 1. 138; Isakymas aviacijai Nr. 45, $1931 \mathrm{~m}$. gruodžio 23 d. LCVA, f. 1323, ap. 1, b. 201, 1. 122; Karo aviacijos ịsakymas Nr. 255, 1934 m. spalio 31 d. LCVA, f. 1323, ap. 1, b. 292, 1. 321; Karo aviacijos issakymas Nr. 167, 1935 m. liepos 20 d. LCVA, f. 1323, ap. 1, b. 318, 1. 197; Karo aviacijos ísakymas Nr. 234, 1935 m. spalio 15 d. LCVA, f. 1323, ap. 1, b. 318, 1. 289; Karo aviacijos itsakymas Nr. 82, 1937 m. spalio 30 d. LCVA, f. 1323, ap. 1, b. 396, 1. 110; Karo aviacijai įsakymas Nr. 71, 1938 m. rugsejjo 1 d. LCVA, f. 1323, ap. 1, b.449, 1. 102; Karo aviacijos įsakymas Nr. 90, 1938 m. spalio 31 d. LCVA, f. 1323, ap. 1, b. 449, l. 122; Karo aviacijos įsakymas Nr. 9, 1938 m. vasario 15 d. LCVA, f. 1323, ap. 1, b. 449, 1. 13; Karo aviacijai itsakymas Nr. 71, $1938 \mathrm{~m}$. rugsejo $1 \mathrm{~d}$. LCVA, f. 1323, ap. 1, b.449, 1. 102; İsakymas Karo aviacijai Nr. 36, 1939 m. gegužès 6 d. $L C V A$, f. 1323, ap. 1, b. 523, 1. 39; Itsakymas Karo aviacijai Nr. 88, 1940 m. spalio 15 d. LCVA, f. 1323, ap. 1, b. 594, 1. 23; Itsakymas Karo aviacijai Nr. 88, 1940 m. spalio 15 d. $L C V A$, f. 1323 , ap. 1, b. 594, 1. 23; Isakymas Karo aviacijai Nr. 70, 1940 m. rugpjūčio 26 d. LCVA, f. 1323, ap. 1, b. 594, 1. 42; Kariuomenès vado isakymas Nr. 29, 1937 m. gruodžio 31 d.; Kariuomenès vado įsakymas Nr. 3, 1938 m. vasario 15 d.; Kariuomenès vado įsakymas Nr. 24, 1938 m. lapkričio 7 d.; Kariuomenès vado įsakymas Nr. 20, 1939 m. birželio 1 d.; Kariuomenès vado 
įsakymas Nr. 28, 1939 m. rugpjūčio 8 d.; Kariuomenès vado įsakymas Nr. 45, 1939 m. lapkričio 3 d.; Kariuomenès vado įsakymas Nr. 52, 1939 m. gruodžio 31 d. [žiūrèta 202001 15]. Prieiga per internetą: <https://www.epaveldas.lt/vbspi/ biSerial.do?biRecordId=2891>; İsakymas kariuomenei Nr. 31, $1932 \mathrm{~m}$. gegužès 14 d. [žiūrèta 202001 15]. Prieiga per internetą: <https://www.epaveldas.lt/vbspi/ biSerial.do?bi RecordId=194362>; Baigusių 1935 m. spalio mèn. 15 d. Karo aviacijos mokyklos kadro karininkų kursų karininkų sąrašas. LCVA, f. 1451, ap. 3, b. 20 1. 25; Karo aviacijos mokyklos viršininko $1937 \mathrm{~m}$. sausio $24 \mathrm{~d}$. raportas Nr. 105 Karo aviacijos viršininkui. LCVA, f. 1451, ap. 3, b. 54, 1. 7; Karo aviacijos mokyklos karininkų kursų IV-tą laidą baigusių sąrašas. LCVA, f. 1451, ap. 3, b. 14, 1. 8; Zabielskas, V. (et. al.) Lietuvos kariuomenés karininkai 1918-1953, t. X. Vilnius, 2015, p. 310-315.

* 1919 m. Karo aviacijos mokyklą baigè 34 absolventai, tačiau iš jų tik 15 dalyvavo Nepriklausomybės kare ${ }^{191}$. Taip pat ne mažiau kaip 14 šios mokyklos absolventų iki $1923 \mathrm{~m}$. pakartotinai mokèsi ir tobulinosi aviacijos kursuose prie Mokomosios eskadrilès. Iš 34 tik 22 vykdè užduotis, susijusias su skraidymu.

** $1929 \mathrm{~m}$. gruodị kursus baigė 11 karių, iš jų dèl nepažangumo vienam neleista mokytis skraidyti. $1931 \mathrm{~m}$. išlaikius egzaminus, dar 2 kariai buvo laikomi baigę 1929 m. kursus.

*** Karo aviacijos mokyklos laidą baige 23 lakūnai ir jiems buvo suteikti II rango karo lakūno vardai. Gr. Anatolijus Kraucevičius išklausẻ kursą, tačiau neišlaikęs visų egzaminų mokyklos nebaigè. 1939 m. po mokymų jam buvo suteiktas II rango karo lakūno vardas.

**** Karo lakūnų puskarininkių II laidą baigè 15 lakūnų, dar 3 lakūnams mokymasis mokykloje buvo pratęstas ir jie mokyklą baigè 1937 m. gruodžio mèn. Iš mokyklos dèl drausmės pažeidimų pašalintas j. psk. Jonas Dovydaitis, išlaikęs visus egzaminus ir baigęs praktinị lakūno rengimą. Po mokymų $1938 \mathrm{~m}$. jam buvo suteiktas II rango karo lakūno vardas.

***** Karo mokyklos XIX laidą baige 21 aviacijos karininkas, tačiau tik 19 buvo suteiktas II rango karo lakūno vardas. Iki suteikiant karo lakūno vardą j. ltn. Jonas Vidūnas žuvo aviakatastrofoje, o j. ltn. Eduardas Žukauskas paties prašymu išleistas į atsargą.

****** Karo aviacijos mokyklos puskarininkių klasės lakūnų skyrių baigė 15 lakūnų ir dar 5 šią laidą baigè vèliau dèl pratęsto mokymo.

****** Oro šaulių kursą baige 16 absolventų, iš jų 11 karo lakūno vardas suteiktas 1939 m. po kursų, dar 5 - baigus Karo aviacijos mokyklos mechaniku skyriu.

${ }_{* * * * * * * *}$ Karo mokyklos XXI laidą baigè 19 aviacijos karininkų, 16 iš jų buvo

191 Aviacijos dalies 1920-1921 m. karo dienynas. LAM, GEK 4172, 1. 1-56. 
paskirti tarnauti ị karo aviaciją. Visiems paskirtiems ị karo aviaciją karininkams nesuteikti II rango karo lakūnų vardai, išskyrus j. ltn. Aleksą Morkų, kuris buvo baigęs Aviacijos puskarininkių lakūnų ir mechanikų mokyklos II laidą.

\section{IŠVADOS}

Karo aviacijos skraidančiojo personalo atrankos sistema susiformavo $\mathrm{XX}$ a. trečiojo dešimtmečio antrojoje pusejje ir reikšmingai nesikeitè iki pat 1940 m. Modernus ir pabrèžtinai nuodugnus sveikatos tikrinimas buvo svarbiausia kompleksinès atrankos sudedamoji dalis. Vis dèlto pasirinktas atrankos modelis ir selektyvus jo taikymas neužtikrino aviacijos tarnybai tinkamų karių atrinkimo kokybès. 1919-1940 m. atrankos efektyvumas buvo žemas - iš 10 atrinktų karių vidutiniškai tik 4-5 baigdavo pradinę rengimo pakopą, o apie trečdalis kaip nepažangūs ar aviacijos tarnybai neturintys reikalingų gabumų buvo pašalinami dar pirmaisiais mokymosi metais.

Atsižvelgiant ị konceptualius pokyčius, Lietuvos karo aviacijos skraidančiojo personalo rengimo sistemą galima suskirstyti ị du periodus. 19191928 m. naudota dviejų pakopų skraidančiojo personalo rengimo sistema, kurios pagrindą sudarè turiniu ir apimtimi mažai besikeitę trumpalaikiai kursai. Vadovaujantis Pirmojo pasaulinio karo patirtimi šioje sistemoje nepagrịstai mažai dėmesio buvo skiriama pradiniam skraidančiojo personalo teoriniam ir praktiniam rengimui. Rengimo sistemos netolygumas pasireiškè išaugusiu žuvusiųjų skaičiumi ir sulètejusia karo aviacijos plètra. $\mathrm{XX}$ a. trečiojo dešimtmečio pabaigoje skraidančiojo personalo rengimo sistemos konceptualius pokyčius lėmė kvalifikacinių vardų suteikimo susiejimas su rengimo sistema. 1929-1940 m. - antrasis skraidančiojo personalo rengimo sistemos laikotarpis, kai buvo pereita prie trijų pakopų rengimo sistemos, kuri sudare prielaidas kokybiškiau rengti karo aviacijos skraidantijji personalą. Perejus prie trijų pakopų rengimo sistemos, buvo sustiprinta pirmoji pakopa, ikurta Karo aviacijos mokykla ir sudarytos sąlygos rezultatyvesniam rengimui. $1934 \mathrm{~m}$. trijų pakopų rengimo sistemą galutinai konsolidavus, skraidančiojo personalo rengimo sistema kokybiškai skyrėsi nuo iki 1934 m. funkcionavusios sistemos. Visų pirma įvykę pokyčiai leido sukurti profesionalią pradinio teorinio ir praktinio rengimo pakopą.

Karo aviacijos skraidančiojo personalo rengimo sistemai nuolatinis iššūkis buvo patenkinti dèl iš tarnybos pasitraukusių parengtų karių su- 
sidariusị skraidančiojo personalo poreikị. Nuo XX a. 3-4 dešimtmečio sandūros skraidančiojo personalo rengimo sistema buvo pajègi ne tik patenkinti šị poreikị, bet ir parengti Lietuvos karo aviacijos plètrai būtiną lakūnų ir oro žvalgų skaičių.

\section{ŠALTINIŲ IR LITERATŪROS SĄRAŠAS}

\section{Nepublikuoti šaltiniai}

Lietuvos centrinis valstybès archyvas (LCVA)

f. 509 - I pèstininkų divizija

f. 531 - Karo aviacijos grupès, eskadrilès ir teismai

f. 631 - Vytauto Didžiojo universitetas

f. 930 - Krašto apsaugos ministerijos ịstaigų ir karinių dalinių asmens sudèties dokumentų kolekcija

f. 1323 - Karo aviacija ir Karo aviacijos karininkų ramovè

f. 1451 - Karo mokyklos ir kursai

Lietuvos aviacijos muziejus (LAM)

GEK 4172 - Aviacijos dalies 1920-1921 m. karo dienynas

GEK 15526 - Gustaitis, A. Aerodinamikos konspektas. Kaunas, 1924.

GEK 15528 - Gustaitis, A. Aviacijos teorijos konspektas. Kaunas, 1924.

\section{Publikuoti šaltiniai}

Aklasis skraidymas. Kaunas, 1939.

Artilerijos ir aviacijos bendradarbiavimo statutas A-56. Kaunas, 1937. Aviacijos daliu stovejjimo vietos ir žygiai. Aviacijos lauko tarnybos statutas Av-3. Kaunas, 1932.

Aviacijos naikintuvu statutas Av-55, Kaunas, 1937.

Žvalgomosios aviacijos statutas Av-58. Kaunas, 1939.

Šviesinis taikytuvas. Kaunas, 1938.

Lèktuvinis brauningo kulkosvaidis 35 ir 36. Kaunas, 1939.

Gustaitis, A. Aviacijos teorijos konspektas. Aerodinamika ir skridimo 
mechanika. Kaunas, 1935.

Kraucevičius, J. Aviacijos kurso konspektas. Kaunas, 1928.

Bendros meteorologijos ir aeronavigacijos žinios. Kaunas, 1924.

Gustaitis, A. Aviacijos istorijos konspektas. Kaunas, 1924.

Gustaitis, A. Pilotažo vadovélis. Kaunas, 1936.

Gustaitis, A. Skridimo mechanika, Kaunas, 1937.

Januškevičius, Č. Skraidymo vadovèlis. Kaunas, 1939.

Landsbergis, L. Avigaciniai žiroskopiniai prietaisai. Kaunas, 1938.

Mikènas, J. Aviacijos varikliai. Kaunas, 1934.

Porter, H., E. Oro žvalgyba. Kaunas, 1931.

Reimontas, V. Avigacijos vadovélis. Kaunas, 1938.

Reimontas, V. Bombu mètymas. Kaunas, 1934.

Mikènas, J. (vert.) Taisykles motoru Fiat A-20 ir A-22 vartojimui. Kaunas, 1929.

Morkus, V. Aerodromu parinkimas. Kaunas, 1929.

Vaivada, B. Aeronautine meteorologija. Kaunas, 1931.

\section{Memuaristika}

Abraitis, J. PLP Karo mokyklos XIX laidos 5-tis. Karys, 1988, balandis, Nr. 4 (1641).

Baipšys, S. Nuotykiai padangèje ir žemèje. Kaunas, 1995.

Brazys, B. Gyvenimas ir tarnyba. Plieno sparnai, Nr. 2, 1994.

Dovydaitis, J. Nepriklausomybès kovu lakūnai. Kaunas, 2014.

Hiksa, P. Gyvenimas kaip skrydis. Vilnius, 2014.

Laurinaitis, J. M. Karo aviacijos mokyklą prisimenant. Karo archyvas, t. 1, 1925.

Mikènas, J. Gyvenimo skrydis. Kaunas, 1994.

Mikènas, J. Karo aviacijos pirmoji eskadrilè. Plieno sparnai, Nr. 1, 1992.

Mikutis, A. Lietuvos karo aviacijos tarnyboje 1936-1940. Plieno sparnai, Nr. 1, 1992.

Navaitis, A. Šimtmečio skrydis. Karo lakūno atsiminimai. Vilnius, 2017.

Peseckas, L. Karo lakūno pasakojimai. Kaunas, 2006.

Pyragius, J. Kovosiu, kol gyvas. Kaunas, 1993.

Pyragius, J. Lietuvos karo aviacijos tarnyboje. Plieno sparnai, Nr. 5, p. 1998. 
Rimas, K. Kpt. K. Rimas prisimena... Plieno sparnai, Nr. 4, 1973.

Seliokas, J. Karo lakūno odisèja. Plieno sparnai, Nr. 5, 1998.

Stanaitis, S. Lietuvos savanorio-kürëjo, karo lakūno, Karo invalidu sqjungos pirmininko, šachmatu rinktines kapitono, Gulago kalinio likimo vingiai. Kaunas, 1992.

Vaičeliūnas, J. Tẻvynès sargyboje. Sudbury, 1955.

\section{LITERATŪRA}

Ažubalis, A. Matematikos taikymas Lietuvos kariuomenèje 1918$1940 \mathrm{~m}$. Vilnius, 2015.

Barkauskas, S. Medicinos tarnyba aviacijoje ir aviacijos gydytojas. Mūsų žinynas, Nr. 29, 1926.

Gamziukas, A. Antanas Norèjo Būti Ore. Kaunas, 1997.

Gamziukas, A. Aviacija Lietuvoje 1919-1940 m. Kaunas, 1993.

Gruzdiené, E. Lietuvos karo aviacijos lakūnų ir žvalgų rengimas 1919-1932 m. Karo archyvas, t. XIX, 2004.

Gustaitis, A. Lakūnų ir žvalgų mokymas mūsų aviacijoje. Kardas, Nr. 14, 1925.

İsteigta puskarininkių lakūnų mokykla. Karys, 3(503), 1929.

Jakštas, P. Lietuvos karinè spauda 1918-1938. Mūsu žinynas, Nr. 1112 (165-166), 1938.

Jonaitis, M. Aspirantų tarnyba: studentiška karo prievolès alternatyva (1926-1940 m.). Kariūnas, Nr. 2 (125), 2015.

Jonaitis, M. Aspirantų tarnyba: studentiška karo prievolès alternatyva (1926-1940 m.). Kariūnas, Nr. 3 (126), 2015.

Kariuomenes leidiniu 1918-1931 m. katalogas. Kaunas, 1932.

Kasparaitė-Balaišè, L. Lietuvos kariuomenès kovos statutai XX a. 3-4 dešimtmetyje. Karo archyvas, t. XXXIII, 2018.

Knezys, S. Lietuvos kariuomenès karo mokykla 1919-1940 metais. Lietuvos kariuomenés karininkai 1918-1953. II tomas. Sud. B. Kulnytė. Vilnius, 2002.

Kulnyte, B. (et. al.) Lietuvos kariuomenès karininkai 1918-1953, t. IIVIII. Vilnius, 2002-2008.

Lesčius, V. Lietuvos kariuomenès 1918-1920 m. Vilnius, 1998.

Lesčius, V. Lietuvos kariuomenès organizavimo, dislokavimo ir 
ginkluotés pokyčiai 1938-1940 m. Karo archyvas, t. XXIV, 2009.

Liekis, A. Lietuvos karo aviacija (1919-1940). Vilnius, 1999.

Lukšys, S., Mintautas, R., Monkevičius, J. Palūžę sparnai. Vilnius, 1997.

Pyragius, J. (red.) Mūsų sparnai. Lietuvos aviacijos istorija 1919-1929. Kaunas, 1929.

Puzinavičius, B. Karininkas - pedagogas ir vadas (pagal 1921-1940 m. Lietuvos kariu spaudos publikacijas). Karo archyvas, t. XXI, 2006.

Puzinavičius, B. Karininkų rengimo ir kvalifikacijos kèlimo sistema tarpukario nepriklausomoje Lietuvoje (1919-1940 m.). Karinis rengimas ir ugdymas Lietuvoje. Sud. B. Puzinavičius, N. Janulaitienè. 2007.

Ramoška, G. ANBO II. Pirmasis lietuviškas mokomasis lèktuvas. Plieno sparnai, Nr. 5, 1998.

Ramoška, G. Lèktuvai, pagaminti Kaune. Plieno sparnai, Nr. 4, 1997.

Ramoška, G. Lietuvos aviacija. Kaunas, 2009.

Ramoška, G. Pirmieji Lietuvos karo aviacijos lèktuvai 1919-1923 m. Plieno sparnai, Nr. 1, 1992.

Raubickas, E. Ženklas ant munduro. Vilnius, 2005.

Rezmer, W. Litewskie lotnictwo wojskowe 1919-1940. Toruń, 1999.

Rutkiewicz, J. Kulikow, N. W. Wojsko litewskie 1918-1940. Warszawa, 2002.

Statkus, V. Lietuvos ginkluotos pajégos 1918-1940 m. Chicago, 1986.

Štulas, S. Apie A. Liekio knygą „Lietuvos karo aviacija (1919-1940)“ [interaktyvus], 20090203 [žiūrèta 201910 14]. Prieiga per internetą: <http://www.plienosparnai.lt/page.php?318>

Tupčiauskas, V. Lakūnų mediciniškas parinkimas ir jų sveikatos kontrolè. Lietuvos sparnai, 1934, balandis, Nr. 4.

Vaivada, B. Lakūnų psichotechnika. Mūsų žinynas, Nr. 73, 1931.

Zabielskas, V. (et. al.) Lietuvos kariuomenes karininkai 1918-1953, t. X. Vilnius, 2015.

Žigaras, F. Karininku rengimo ir ju kvalifikacijos kèlimo sistema 19191940 m. I dalis. Vilnius, 2018.

Žigaras, F. Karininkų rengimo ir ju kvalifikacijos kèlimo sistema 19191940 m. II dalis. Vilnius, 2018.

Iteikta $2020 \mathrm{~m}$. balandžio $14 \mathrm{~d}$. 


\title{
AIRCREW TRAINING SYSTEM IN THE LITHUANIAN MILITARY AVIATION IN THE PERIOD OF 1919-1940
}

\author{
Mindaugas SEREIČIKAS, \\ Klaipeda University, Institute of Baltic Region History and Archaeology
}

The Lithuanian military aviation was established in 1919. It provided pilot and air reconnaissance training. Until 1940, the aircrew training system had been modified and improved several times for greater efficiency and effectiveness.

Attempts to find the balance between the eligible candidates and the willing ones to become pilots were not successful until 1940. The Lithuanian military aviation failed to develop an efficient selection system. The comprehensive selection system consisted of regularly reviewed age and education censuses, test flight and physical fitness check. The latter became a key component of the selection in the period from 1917 to 1929. However, out of 10 candidates selected for pilot service, on average only 4-5 soldiers completed the initial training stage, whereas about a third were excluded as incompetent or lacking necessary skills for the aviation service during the first years of combat training.

In the period from 1919 to 1928 , the aircrew training was divided into two stages: short-term courses and individual training in a squadron. During this period, combat training was not standardized, it was based mainly on the experience of the pilots of the World War I. Up to 1928, it was not determined what knowledge and skills a pilot or an air scout must acquire having completed the whole training system. Both training levels completely depended on teachers of theoretical disciplines and flight instructors.

Conceptual changes in the aircrew training system took place in 1929 when a three-level training system was established on the initiative of the Military Aviation Command. A transition to the three-level training system led to the institutional changes, i.e. the establishment of the Military Aviation School in 1932. Since 1934, the school focused on the basic theoretical and practical individual combat training for soldiers of 
all specializations necessary for the aviation service. In the period from 1929 to 1940, in addition to the first level of basic training, the second and third levels took place in squadrons. The standardization of the training programmes started in 1929 and were based on coherent training programmes. The three-level training system enabled the school to train the pilots of higher qualification.

In the period of 1919-1940, 305 pilots and air scouts completed the first stage of training and continued their service in military aviation. However, the aircrew training system faced a constant challenge to meet the need of the aircrew personnel due to the withdrawal of trained soldiers from the military service. From 1927 to 1928, the effectiveness of the training system did not meet the needs of the military aviation as the number of pilots after the first stage of training was too small due to the poor selection. Starting from the turn of 1930, the effectiveness of the aircrew training started to increase annually and the necessary number of pilots and air scouts for the development of military aviation was ensured. 